\title{
Nós Ainda Brincamos Como Vocês Brincavam?
}

\author{
Ingrid Dormien Koudela \\ Universidade de São Paulo - USP, São Paulo/SP, Brasil \\ E-mail: idormien@usp.br
}

\section{Resumo}

Abstract

Na pintura Children's Plays (Pieter Bruegel, The Elder/1525-1569) o artista renascentista fez o inventário de oitenta jogos. Este é um modelo da maior grandeza, ancorado que está na ancestralidade. A alegoria, tanto em suas manifestações icônicas quanto literárias traz um grande potencial para a construção de metáforas frente às crescentes ameaças que assolam a humanidade. A abordagem através de procedimentos de caráter coral e natureza lúdica pode abrir novamente uma vertente poderosa para a Pedagogia das Artes Cênicas. Os procedimentos de encenação serão sempre novos, na mesma medida em que identidades se constituem continuamente e as formas que os jogos teatrais assumem são polifônicas. O registro da encenação que descrevo almeja mostrar como foi o processo de ensino/aprendizagem, na esperança que esse patrimônio de cultura oral não seja esquecido no futuro que nos aguarda.

Palavras-chave

Pedagogia das Artes Cênicas. Alegoria. Jogo teatral.
In the painting Children's Plays (Pieter Bruegel, The Elder/1525-1569) the renaissance artist does the inventory of eighty games. It is a model of greatest greatness since it is anchored in ancestry. The allegory, in iconic as in literary manifestations brings a big potential for the construction of metaphors in front of growing menaces that plague humanity. The approach through procedures of choral character and ludic nature can open again a powerful shed in the Pedagogy of Performance. The procedures of staging will be always new, since identities change continuously and the forms theater games take are polyphonic. The register of the staging I describe seeks to show how was the process of teaching/ learning, in hope that this patrimony of oral culture will not be forgotten in the future that attends us.

Keywords

Pedagogy of Performance. Allegory. Theater games. 
Como educar. Como pensar o corpo de meninas e meninos a partir da escola, em geral um ambiente disciplinador e amansador dos corpos pulsantes? A educação está fora dos muros escolares. Se a escola não reconhecer isso, pior para ela $\mathrm{e}$ para quem ela educa. Aí mora o problema. Os toques de tambor têm voz. Maria PadiIha desceu a serra, corpo de mulher livre, rodopiando como ventania. Precisamos de outras vozes, politicas porque poéticas, musicadas, da sabedoria dos mestres das academias, mas também das ruas e de suas artimanhas de produtores de encantarias no precário. A escola colonial, tão presente, busca educar corpos para o desencanto e para os currais do mercado de trabalho normatizados pelo medo de driblar/gingar/pecar. Que se cruzem as filosofias diversas, no sarapatel que une Bach e Pixinguinha, a semântica do Grande Sertão Heráclito e Exu, Spinoza e Pastinha, a biblioteca e a birosca. Que se cruzem notebook e bola, tambor e livro, para que os corpos leiam e bailem na aventura maior do caminho que descortina o ser naquele espaço que chega a ser maior que o mundo: a rua. (SIMAS, 2020, p. 55).

\section{Introdução}

$\mathrm{Na}$ epígrafe acima, Simas formula o reexistir, o reinventar de terreiros improváveis que poderão nos ajudar a historicizar os cinco séculos que nos separam da alegoria brugeliana da praça pública renascentista.

Ingressei como Docente do Curso de Graduação na UNISO ${ }^{1}$, a convite do Prof. Dr. José Simões de Almeida, em fevereiro de 2006, com a incumbência de encenar espetáculo teatral a ser preparado com a primeira turma de formandos do Curso de Licenciatura em Teatro. À coordenação pedagógica do curso, do Prof. Simões de Almeida, deve-se uma articulação curricular que permitiu liberdade e rigor no processo de encenação. Coube a ele ainda o cuidado com a produção da montagem, aberta ao público de Sorocaba.

1 UNISO - Universidade de Sorocaba/Estado de São Paulo.
Figura 1. Prof. Dr. José Simões de Almeida. Teatro Municipal Teotônio Vilela no dia 21 de junho de 2006.

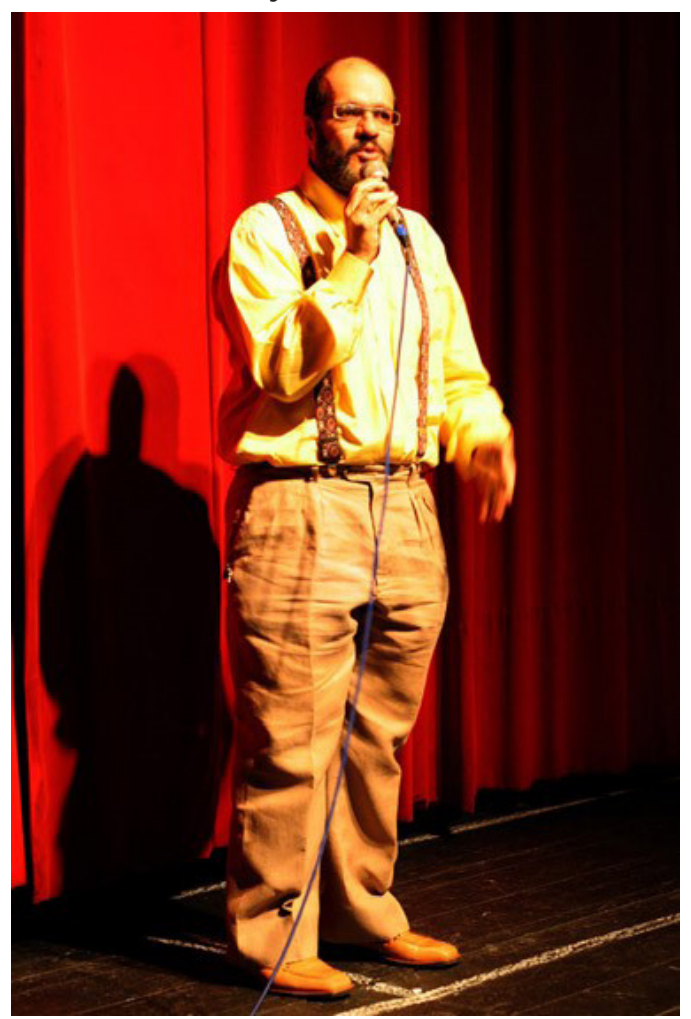

Fonte: Arquivo pessoal da autora.

Os tambores e o canto do músico Ramon Vieira, as tesouras e agulhas das costureiras coordenadas pela artista Élena Toscano, a pontuação da iluminação de Gil Camargo e a assistência de direção de Raquel Ornellas formaram um coletivo interdisciplinar que permitiu tecer um processo colaborativo entre docentes e alunos.

A encenação é prevista no currículo do Curso de Licenciatura, através das disciplinas Atuação e Montagem Teatral, cada qual com carga horária de quatro horas-aula semanais. Neste relato, dou ênfase maior à disciplina Atuação, já que o processo se deu a partir do jogo do atuante em cena.

A encenação de Nós Ainda Brincamos Como Vocês Brincavam? é o resultado do planejamento e das aulas nas duas disciplinas: Atuação e Montagem Teatral. A dramaturgia do texto cênico foi elaborada a partir da pesquisa realizada com os alunos e apresentada no Teatro Municipal Teotônio Vilela no dia 21 de junho de 2006, aberta para 
o público em geral. A encenação, sua dramaturgia e direção, seu registro e processo pedagógico estão documentados na presente publicação.

Durante o segundo semestre de 2006 lecionei a disciplina Teatro Educação para o mesmo grupo de formandos, ocasião em que procedemos à avaliação do processo de montagem e atuação e elaboramos seus desdobramentos educacionais. Objetivo dessa avaliação com os alunos formandos foi a formulação de novos projetos pedagógicos, por eles iniciados, na comunidade de Sorocaba e do Estado de São Paulo.

\section{Bases teóricas}

Figura 2. O modelo de ação.

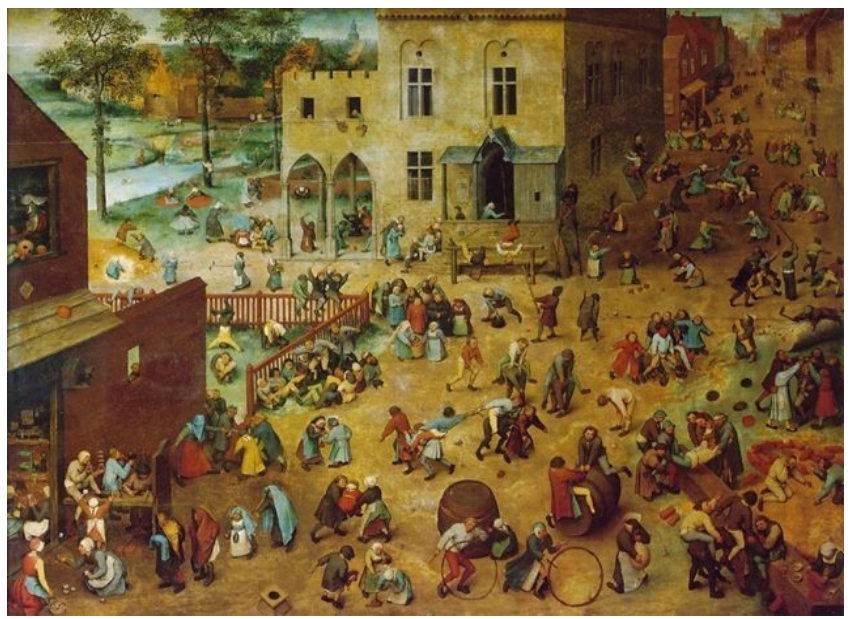

Fonte: Children's Plays, Wikimedia Commons,

Public Domain.

Aleitura de imagem da obra de Pieter Bruegel que forneceu o modelo de ação da encenação, propõe inúmeras tarefas de articulação da Pedagogia do Teatro implicadas na encenação como prática pedagógica.

O conceito de modelo de ação nasce da teoria do Lehrstück de Bertolt Brecht que propõe dois instrumentos didáticos para a experimentação prática: o modelo de ação e o estranhamento. O texto da peça didática assume função modelar ao ser imitado, sendo ao mesmo tempo objeto de critica - a poesia/literatura é apreendida de forma processual (ela não contém verdade em si mesma). Os modelos de ação são determinados, ou seja, nitidamente delineados, isoláveis em suas partes para que possam ser julgados ou imitados. Frases pouco claras e gradações dramáticas que exijam interpretações a partir do temperamento não têm lugar na peça didática. Característica do modelo é sua reprodutibilidade por qualquer pessoa. Por outro lado, o jogo teatral com base no texto de Brecht não é apenas um desempenho de papéis (role-playing) que parte unicamente das experiências pessoais dos jogadores ou do contexto grupal. O texto é o móvel de ação, o pretexto e ponto de partida da imitação critica que são introduzidas na improvisação e nas rodas de conversa.

Figura 3. Detetive e Ladrão:

Jogo Teatral dos atuantes

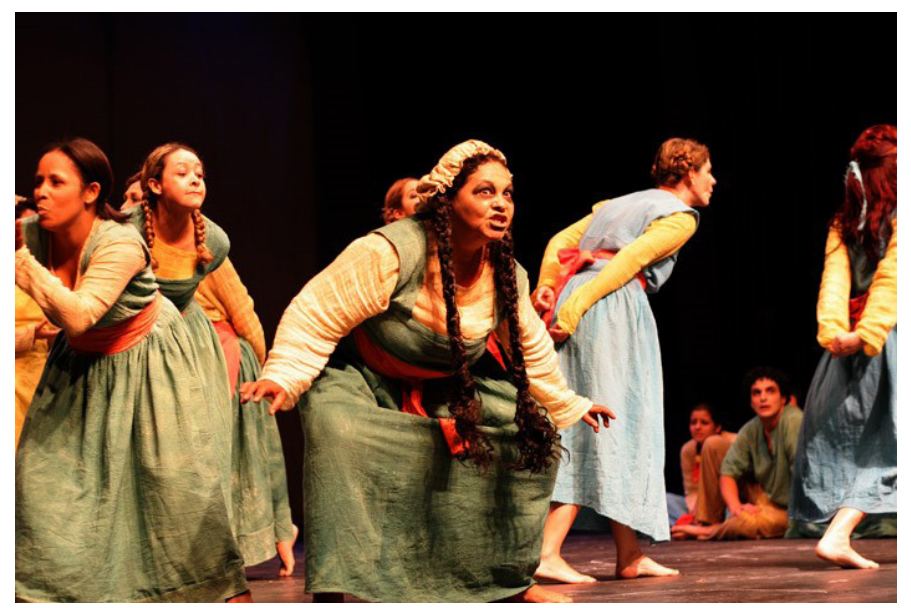

Fonte: Arquivo pessoal da autora.

No jogo com o modelo de ação brechtiano, o autor/ator do processo de conhecimento é o aluno, que constrói os significantes através dos gestos e atitudes experimentados no jogo teatral. Objetivo maior do jogo com o modelo de ação brechtiano não é levar o aluno a aprender um conteúdo específico, mas sim ensinar/aprender o jogo dialético de raciocínio, como participante de um processo de conhecimento. Ao mesmo tempo, o limite colocado pelo modelo de ação abre a oportunidade para o estabelecimento do foco coletivo. O modelo de ação delimita a intervenção educacional no processo criativo.

O caráter estético do experimento com a peça didática é um pressuposto para os objetivos da aprendizagem. Resultam daí as conseqüências para a forma de atuação. Em oposição a um 
processo de identificação, o objetivo da aprendizagem é unir a descrição da vida cotidiana à evocação da história, sem reduzir uma à outra, mas sim com vistas ao reconhecimento de características que são típicas, e que podem ser identificadas em determinada situação social. O estranhamento, entendido como procedimento didático-pedagógico, visa exatamente possibilitar, pelos meios do jogo teatral, o conhecimento veiculado pela forma estética, que está prefigurada no modelo de ação.

Figura 4. Inventário dos jogos.

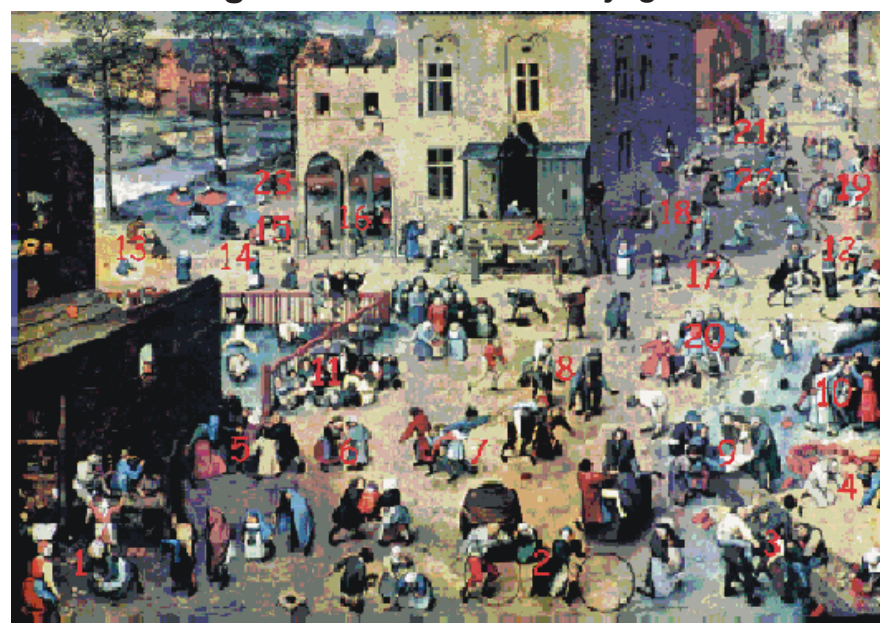

Fonte: Children's Plays, Wikimedia Commons,

Public Domain.

O texto espetacular de Nós Ainda Brincamos Como Vocês Brincavam? nasceu da obra alegórica de Pieter Bruegel que representa duzentas e cinqüenta crianças brincando na praça renascentista. Essa imagem foi eleita a partir da pesquisa realizada com os alunos formandos da primeira turma do Curso de Licenciatura em Teatro. A obra de Bruegel foi assim transformada em modelo de ação para a investigação e experimentação coletiva. Entendemos por modelo, ampliando a concepção brechtiana, a obra de arte, substituindo aqui um modelo literário (texto da peça didática) por um modelo de arte visual. O conceito brechtiano não deve permanecer restrito, a nosso ver, aos fragmentos criados pelo dramaturgo, podendo ser entendido enquanto articulação estética de significados, tais como se apresentam na obra de Brugel, por exemplo.
O próprio Brecht elege a obra de Bruegel como modelar, ao falar, por exemplo, no "efeito de estranhamento na obra narrativa de Peter Bruegel" (BRECHT, 1967, p. 280).

Com o objetivo de instaurar o debate sobre o jogo popular introduzi a imagem Children's Plays a partir da qual discutimos este repertório de cultura oral que na maioria das vezes é hoje lamentavelmente pobre, o que se acentua nas grandes cidades, onde o seu espaço, a rua, é cada vez mais restrito. Encontramos aqui refletida a censura corporal na forma enrijecida dos versos repetidos mecanicamente, na regra de jogo aceita passivamente.

\section{Metodologia}

Experimentamos em sala de ensaio jogos de rua, cantigas e danças dramáticas brasileiras que fazem parte dos sistemas significantes cujo arranjo e interação formam a encenação de Nós Ainda Brincamos Como Vocês Brincavam?

O texto espetacular foi anotado e materializado através de protocolos de ensaio redigidos pelos alunos, considerando a imagem como um modelo produtor de sentido.

Figura 5. Pula Cela, na pintura de Bruegel.

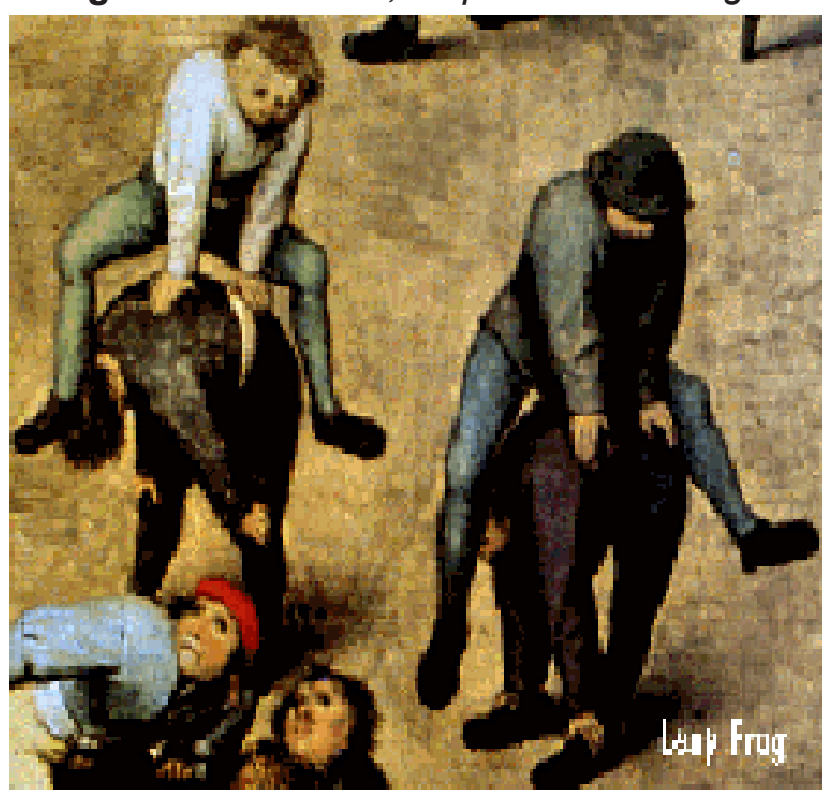

Fonte: Children's Plays, Wikimedia Commons, Public Domain. 
Durante o processo de construção da forma estética que partiu da leitura e apreciação da obra de Bruegel, trabalhamos com partituras corporais. Os jogadores construíram assim um painel no qual a articulação da linguagem gestual ganhava forma.

Figura 6. Pula Cela, no jogo teatral dos atuantes.

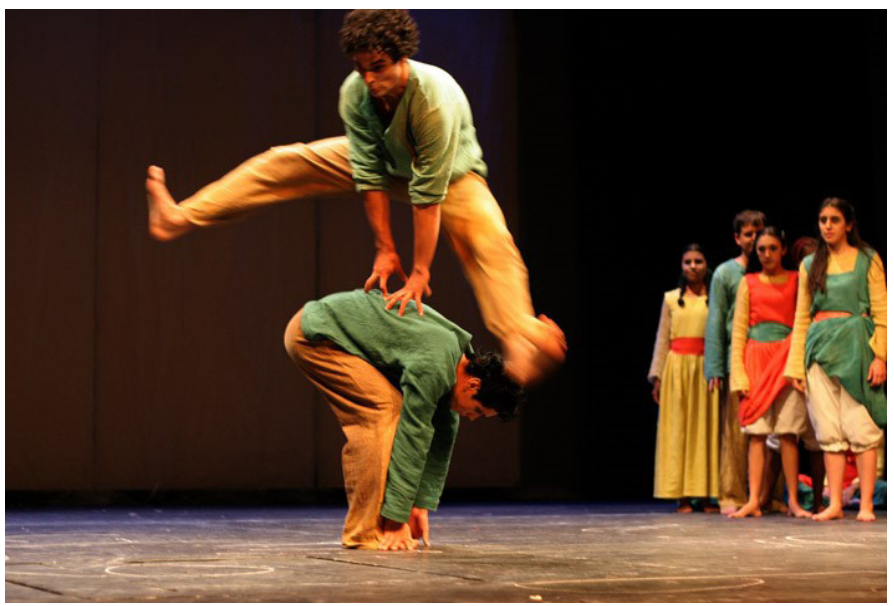

Fonte: Arquivo pessoal da autora.

A escritura dos protocolos de memória do jogo, inicialmente oral, foi retomada por escrito e novamente experimentada cenicamente. Os jogos teatrais foram especificamente direcionados para a construção destas narrativas, posteriormente incorporadas na montagem.

Indumentária e expressões fisionômicas são perscrutados pelos alunos durante o processo de aprendizagem sistematizado a partir da leitura da forma estética da obra. Os rostos das crianças camponesas! Difícil definir a idade. Rostos chapados, sem expressão de alegria ou pesar estão como que desdramatizados. Identificamos os nomes dos jogos e suas regras e os brinquedos foram inventariados e transformados em adereços de cena.

Do jeito que as coisas vão indo, o sinal é de morte, dizia Mario de Andrade (ANDRADE, 2015), referindo-se ao patrimônio da cultura oral, recolhida em suas viagens pelo Brasil. A utopia deixa de ser quimera quando o jogo é instaurado aqui/agora, em espaços que se transformam no topos deste outro teatro em que o corpo do brincante experimenta gestos e atitudes. A explosão da memória do jogo tornou-se utopia concreta quando os alunos encontraram parceiros de jogo.
Figura 7. Balança Caixão, na pintura de Bruegel.

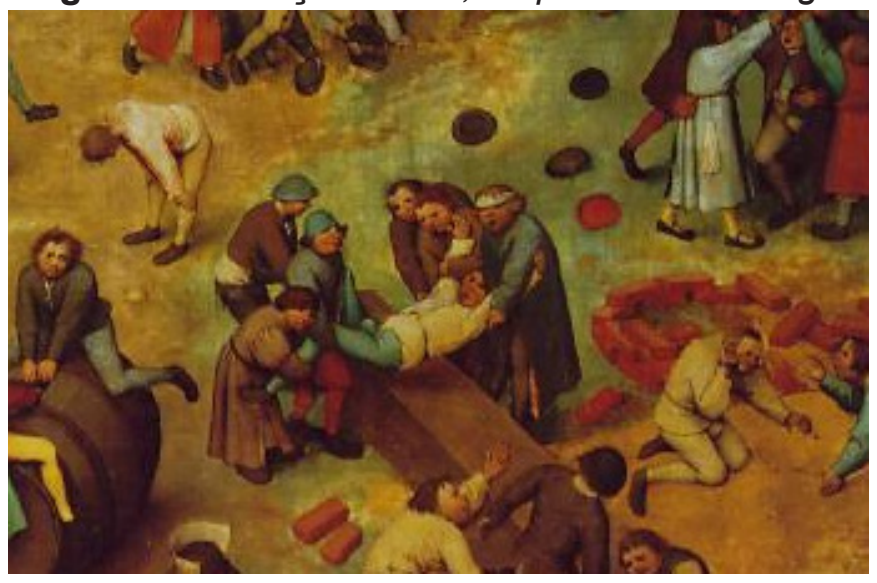

Fonte: Children's Plays, Wikimedia Commons, Public Domain.

A capacidade imaginativa desenvolvida no jogo oferece um número muito maior de hipóteses do que aquelas que a realidade física nos permite experimentar. A tematização do jogo, gerada na ação lúdica, objetiva-se artisticamente, transformada em teatro. Característica antropológica mais marcante do homem, o jogo é núcleo incandescente para a capacidade de exercitar o convívio e construir significados através de experimentos de caráter estético.

Figura 8. Balança Caixão, no jogo teatral dos atuantes.

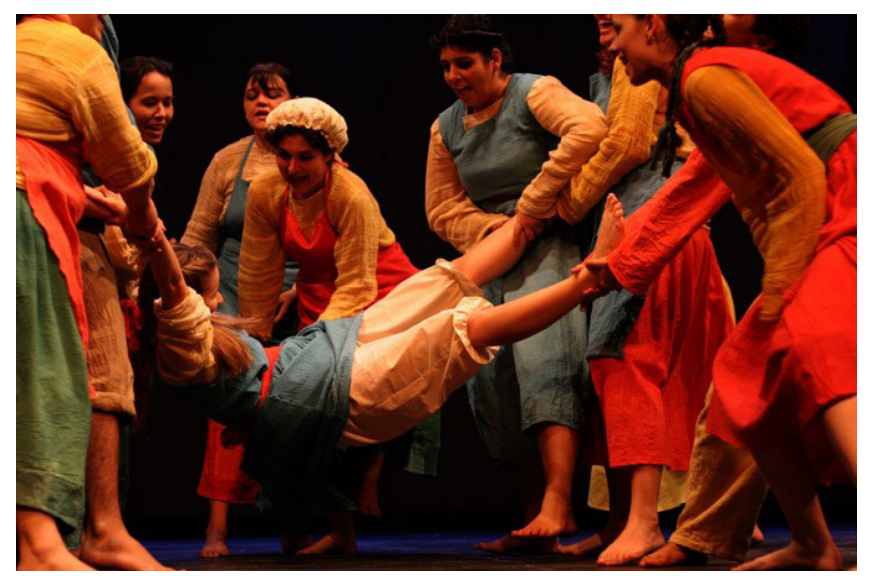

Fonte: Arquivo pessoal da autora.

O exercício do jogo se torna cada vez mais urgente! Processo multiplicador, o desejo é que os professores formandos em teatro encontrem espaços para a concretização desta utopia ainda tão distante de nossos sistemas de educação. 


\section{Avaliação}

O protocolo é um instrumento de avaliação do processo teatral que visa surpreender o momento espontâneo do jogo, registrando os ensaios e contribuindo para a problematização do modelo de ação experimentado em cena pelos atuantes.

Seguem os protocolos, através dos quais registramos o processo e a metodologia da encenação. Os alunos trazem assim seus depoimentos ${ }^{2}$.

Nos primeiros encontros e durante o processo pude compreender a concepção de contemporaneidade. Ela está muito além do simples fato de algo ser atual, de ser novo, de ser inovador. O teatro contemporâneo propõe novas formas na busca por espaços alternativos (não-convencionais), uma linguagem que rompa a dramaticidade do teatro tradicional ocorrendo uma dissolução de gêneros. A dramaturgia quebra a linearidade e o psicologismo das personagens, diminuindo a lacuna entre texto e cena. A partir da leitura da obra de Peter Brugel, o trabalho desenvolveu-se através da historicização e tradução intersemiótica do quadro para o teatro. A historicização compreende a contextualização da obra na forma da sua tradução cênica e através da dramaturgia ao trabalhar com os jogos populares. Estes conceitos foram muito relevantes, pois complementaram os estudos que realizo no grupo Katharsis em busca de um teatro orgânico e de um texto e cena que evoluam juntos e construam um teatro genuíno na corporeidade da voz e do gesto. (Luiz Fernando Esparrachiari Dias).

A pintura primeiramente aparece como interferência externa e aos poucos vamos construindo nossa própria pratica. Nossas narrativas da memória estavam presentes na discussão do quadro. A leitura e apreciação do quadro serviram como modelo de ação para criação de um repertório de partituras de gestos e movimentos, com base na imagem e nas nossas memórias. (Douglas de Camargo Emílio).

\section{Partituras gestuais}

As partituras foram, de início, construídas individualmente. Elas nasceram da memória que cada atuante trouxe de momentos de sua infância. Fazendo um recorte, cada qual mostrou uma seqüência de três gestos para o grupo, fisicalizando gestos e atitudes, numa sequência congelada.

Figura 9. Tumba la tumba, jogo teatral dos atuantes.

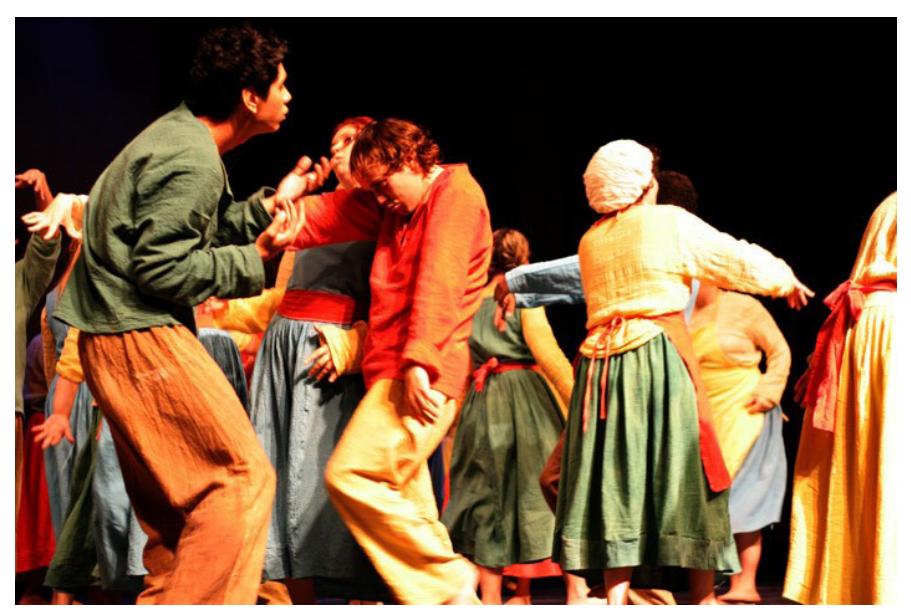

Fonte: Arquivo pessoal da autora.

A partitura individual foi experimentada e criticada/completada com sugestões do grupo:

Ingrid sugeriu que cada intérprete criasse três partituras, de gestos, das brincadeiras que resgatamos, explorando o gesto do corpo e a brincadeira escolhida pelo aluno. Para mim foi muito emocionante criar essas partituras, já que escolhi as brincadeiras que mais gostava. Pipa, vivo ou morto e esconde-esconde. Estas partituras foram criadas, portando, com base nas nossas criações pessoais de gestos e memória dos jogos e inseridas no espetáculo como pulsações. (Danilo Silveira).

2 Os nomes dos autores dos protocolos foram mantidos pois trata-se de uma coautoria na construção da encenação. Os atuantes no jogo teatral não são submetidos a processos psicológicos que exigiriam seu ocultamento. Ao contrário, é importante virem a público. 
Inicialmente surgiram jogos simbólicos (Piage$t)^{3}$ e jogos de rua de forma indiferenciada. Aos poucos, delimitamos o campo de pesquisa para os jogos de rua.

Definimos grupos para pesquisar diferentes tipologias de jogos: jogos de vôo (entre os quais citamos as amarelinhas, os jogos de pula-cela, os corrupios e jogos de equilíbrio corporal); jogos com sons corporais (Nós Quatro; Escravos de Jó); jogos territoriais (entre os quais modalidades de pega-pega como o pegador na linha); jogos obscuros (detetive-ladrão, gato mia). Esta definição das tipologias e o trabalho de inventário dos jogos realizados pelos grupos de atuantes constituíram-se na estrutura da encenação e permaneceram, em forma de partitura, no espetáculo final.

Depois, nos dividimos em grupos, e para cada grupo, foi dado um tipo de jogo. Fiquei no grupo dos jogos sombrios e dos jogos de sons corporais. Nos jogos sombrios, fizemos um levantamento dos jogos que causam alguma tensão, algum arrepio. Fizemos algumas adaptações e a mais interessante foi no jogo do detetive, onde nós passamos a jogar em pé, e não de forma tradicional, sentados. Isso criou uma tensão ainda maior no jogo. (Camila Mantovani Balieiro).

Fazer parte da criação dos jogos sombrios foi algo especial, pois estes eram meus favoritos na infância. Quando pequena, passava horas com meus primos brincando de Gato Mia na garagem escura da casa da minha avó. Eu

3 Ainda hoje, os conceitos piagetianos são reduzidos ao plano de uma psicologia do desenvolvimento na criança, concebidos na perspectiva de faixas etárias estanques. A abordagem do jogo de Jean Piaget $(1975,1977)$ não provém da área de conhecimento da psicologia, mas sim da epistemologia, ou seja, da teoria do conhecimento. Com origem na biologia, seu campo de pesquisa original, as questões colocadas por este autor indagam como se dá a aquisição do conhecimento a partir da sua gênese na criança. A partir da classificação das categorias de jogo propostas por Piaget, historicizo o jogo de regras em seu contexto histórico-social inserido que está no patrimônio da cultura oral. O ponto de partida é nossa memória individual e coletiva do jogo de rua, que leva à reflexão sobre o contexto histórico da obra renascentista e de nossas memórias atuais. O jogo simbólico indaga sobre as relações a serem estabelecidas com a construção da imagem mental e de sua função na expressividade da criança até o artista adulto. tinha a certeza de que quando esses jogos sombrios fossem vistos pela platéia haveria uma avalanche de recordações e isso me estimulou a fazer da melhor forma possível. O grupo foi ficando bastante integrado dando sugestões e todos participaram com prazer, rememorando a sua infância e sentindo o desejo de brincar de verdade. As brincadeiras não são forjadas, não são mecanizadas pelos ensaios, elas são vivenciadas a cada apresentação. O jogo do Detetive deixa muito claro isto, todos jogam de verdade tentando descobrir quem saiu como assassino. (Renata Ribeiro $\mathrm{Ce}$ ).

Por que jogos de vôo? Nas nossas discussões em sala de aula resolvemos dividir os jogos, os jogos de vôo são jogos onde em algum momento ou em todo o momento os pés ficam fora do chão, no ar, ou seja, em vôo. A partir disso começamos experimentando todos os jogos de suspensão no ar, como amarelinha, unha na mula, giros, pulos. Depois criamos transformações nos jogos. Na nossa amarelinha cada quadrado tinha um metro e meio. Com o aumento do tamanho dos quadrados aumentamos os pulos, o tempo e espaço de vôo. Em seguida montamos uma partitura de jogos. (Marcio Ribeiro Murat).

Fiquei responsável em tomar conta dos jogos nos quais o corpo se encontra no ar. Chamamos de jogos de vôo. Coletivamente fizemos um levantamento prévio dos jogos que permitiam essa qualidade corpórea. Tínhamos uma rotina bem interessante. Todos os dias de manhã íamos para o terrão, para pensar e praticar uma pulsação que estava em construção. Cantávamos e dançávamos de baixo do sol gostoso da manhã e só parávamos quando a testa da gente começava a tostar. A partitura de jogos de vôo acontece com quatro jogos (joga pedra do morrinho, amarelinha gigante, unha na mula e giros). O que torna a encenação ainda mais interessante é a presença do coro, que é formado pelas pessoas que não fazem parte das partituras jogadas no momento. O grande diferencial do coro é que a sua presença é dinâmica. A todo o momento ele se modifica permitindo que todos participem. (Douglas de Camargo Emilio) ${ }^{4}$.

4 Descrição espacial do jogo cênico Pula Cela: Extensão da Amarelinha Gigante: um jogador atirava a pedra e ia pulando, no momento em que se abaixava para pegar a pedra, outro jogador inicia o jogo dizendo "estreia nova cela". 
Figura 10. Pula Cela.

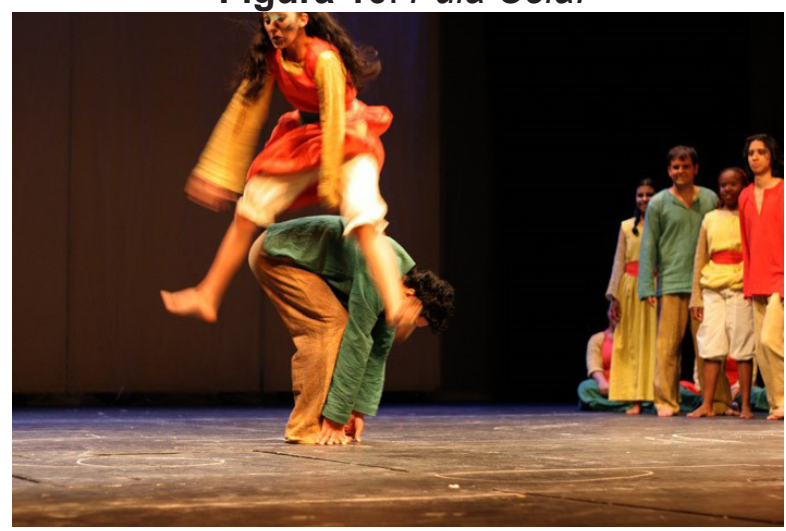

Fonte: Arquivo pessoal da autora.

Figura 11. Construindo a partitura de gestos.

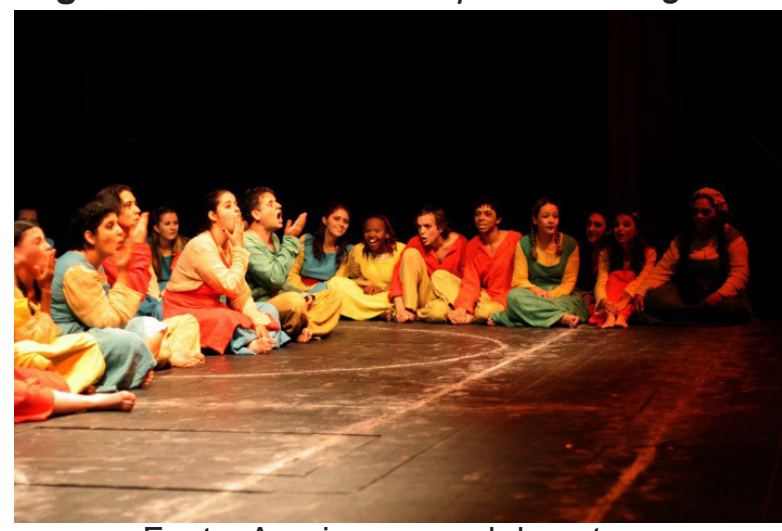

Fonte: Arquivo pessoal da autora.

Após identificarmos os jogos no início do processo, estes foram separados em distintas categorias, pulsações. Todos os jogos que necessitassem de pulos e saltos entraram na pulsação Jogos de Voo, sendo elas: amarelinha, pula cela ou unha na mula, rodopios etc. Os jogos que tinham uma conotação sombria, que eram jogados no escuro ou coisa parecida, formaram a pulsação dos Jogos Obscuros, sendo eles: detetive, corre - cotia, balança caixão e gato mia. Aqueles jogos de palmas e batidas com mãos, pés e outras partes do corpo que formam sons, se tornaram os Jogos de Sons Corporais onde se encontram: Nós quatro, pararo-parati, babalu, 1234, ratatá, lenga la lenga e escravos de Jô. (Danilo Silveira).

A "mula" (como chamamos no interior) ficava no centro do palco, enquanto os jogadores que pulavam ficavam nas extremidades, da direita e da esquerda do palco. Eram ditas cinco frases no decorrer do jogo: "estreia nova sela"; "abriu a porteira"; "pau pica onde cai fica"; "cada macaco no seu galho"; sequência". Só podia não pular ou passar por baixo as personagens que eram café com leite.

\section{Siga o seguidor}

Siga o Seguidor é um fio tecido através de toda a estrutura do processo de jogos teatrais.

Quando todosforeminiciadores Quem ficará para ser o seguidor? Quando todos forem seguidores Quem ficará para ser o iniciador? Quem ficará para ser iniciador e seguidor Quando todos forem iniciadores e seguidores ${ }^{5}$.

Há atores que trabalham com a memória. Eles não se situam no tempo presente, no aqui/agora do jogo teatral. Até mesmo o desempenho do ator mais competente, que domina técnicas de interpretação, quando permanece no passado, deixará os membros da plateia isolados. Os atores devem estar no espaço de cena com a atitude presente para o aqui/ agora do jogo. Enquanto a projeção para o passado/futuro é um processo reflexivo, a relação com o aqui/agora no jogo teatral permite fazer com que o inesperado, o movimento espontâneo seja instaurado. No início ninguém estava entendendo essa forma diferente de atuar, de encenar, de conduzir um espetáculo. Atores que, como eu, estavam acostumados a decorar um texto, estudar uma personagem do ponto de vista stanislaviskiano não conheciam essa nova forma de encenar. O mundo aristotélico e ocidental é dicotômico: o belo e o feio, o claro e o escuro, o bom e o ruim, o sim e o não. E o que existe no meio? E foi justamente no teatro que entendemos essa terceira categoria de trabalho na encenação - a dialética. $O$ que existia até então era decorar, ensaiar, marcar, apresentar - e até receber algum troféu ou reconhecimento financeiro vindo da bilheteria. (André da Silva Barros).

5 Viola Spolin (2001, 2006, 2010, 2012): conhecida internacionalmente por sua contribuição metodológica tanto para o ensino do teatro nas escolas e universidades como para o exercício da performance. A "avó do teatro improvisacional norte-americano", cunhou o termo theatre game, traduzido entre nós como jogo teatral. Os jogos teatrais acentuam a corporeidade, a espontaneidade, a intuição e a incorporação da plateia, indicando como princípios da linguagem teatral podem ser transformados em formas lúdicas, criando um acesso criativo para a performance com leigos e profissionais. 


\section{A instrução no jogo teatral}

As frases usadas para instruir o jogo teatral evocam a descoberta! O professor encenador é o catalisador do esforço coletivo, aquele que busca canalizar as energias dos jogadores e transformar o medo da espontaneidade em uma atitude que promova atenção necessária para estabelecer contato com o desconhecido. Como estimular a intuição? É a intensidade do foco do professor encenador como parceiro de jogo e o uso de instruções habilidosas o estimulo para a expansão do lúdico.

Num primeiro momento trabalhamos com a substância do espaço. Esconder-se do companheiro, revelar-se ao companheiro, atravessar a substância, ser a substância, pegar a substância e trabalhar como se fosse um objeto. Aquilo que Spolin chama de fisicalização6. (André da Silva Barros).

\section{As pulsações da encenação ${ }^{7}$}

A busca do tema - o fio condutor que tece cada pulsação da encenação - se mostra através do gesto do ator e nas artes da encenação: figurino, iluminação, música, espaço.

A partir do inventário de jogos e brinquedos e das improvisações com o Grande Coro, organizamos as pulsações, em diálogo com a gravura de Bruegel.
6 SPOLIN (2012, p. 340).

7 Ibidem, p. 346.
Figura 12. Bolhas de sabão, jogo teatral dos atuantes.

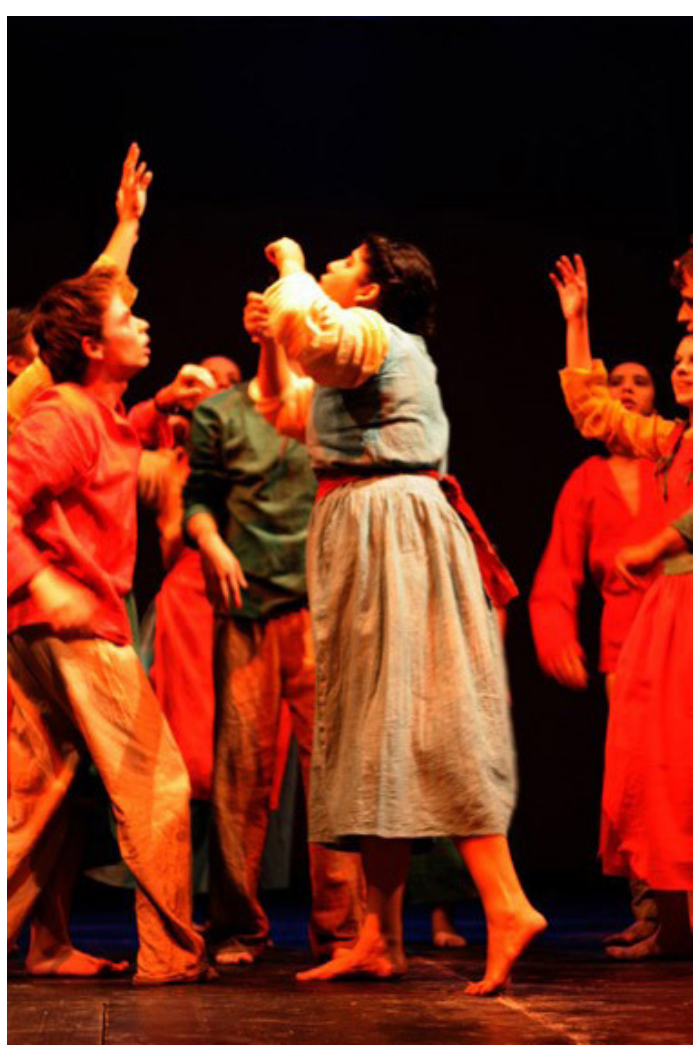

Fonte: Arquivo pessoal da autora.

O tema se mostra no mais simples gesto do ator e nos últimos detalhes do figurino, maquiagem e cabelo (...) o fio condutor que se entrelaça em cada pulsação e unifica todos os elementos durante a sua produção (Ibidem).

Em alguns momentos, foi um verso que nos deu o caminho, outras um gesto construído no jogo de rua. Em processos colaborativos o tema vai se revelando. Importante é não ser rígido em impor um tema prematuramente.

\section{Grande coro e as cantigas e danças populares}

Além da construção das partituras em grupos menores, experimentamos jogos coletivos com o Grande Coro, composto por todos os jogadores participantes (entre eles, Pegador na Linha, Três Mocinhos de Europa, Ruas e Vielas).

Na cena das brincadeiras de roda, cada dia alguém se lembrava de uma brinca- 
deira diferente, e foi difícil escolher as que entrariam em cena. E ainda assim, após algumas apresentações cortamos metade das músicas, pois o espetáculo estava muito comprido." (Camila Mantovani Balieiro).

Figura 13. O Grande Coro.

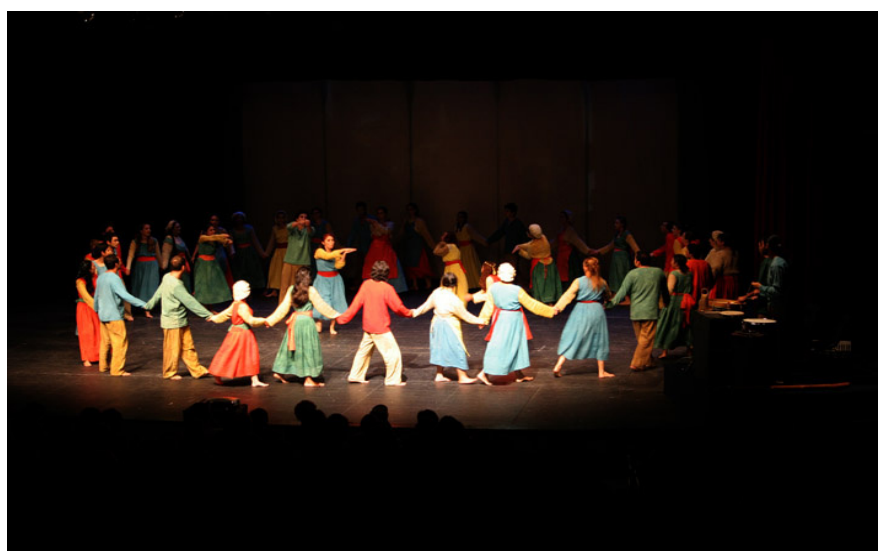

Fonte: Arquivo pessoal da autora.

Figura 14. Corre cotia, jogo teatral dos atuantes.

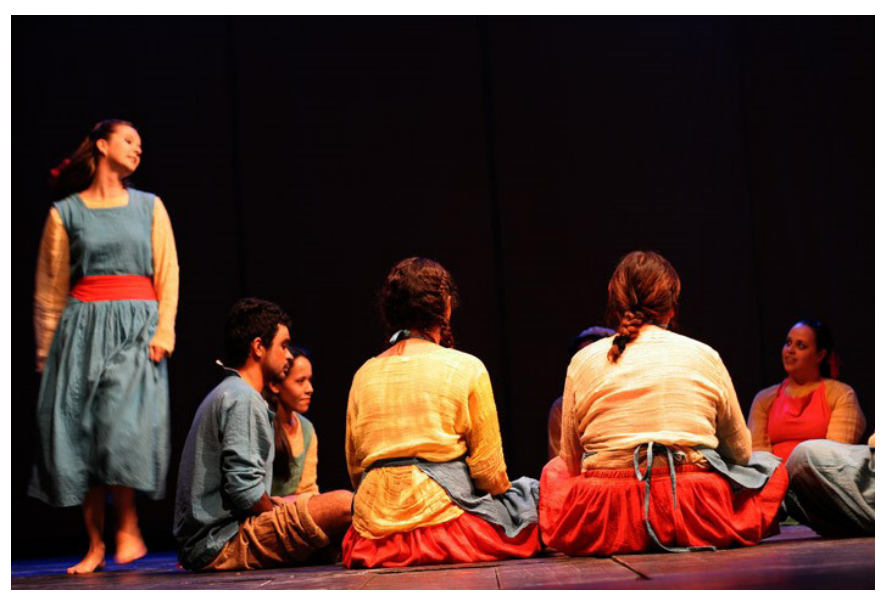

Fonte: Arquivo pessoal da autora.

Durante as primeiras semanas da montagem, ficou evidente para todos que a sala de aula estava pequena para os ensaios. A solução foram os ensaios ao ar livre. Além da pesquisa de jogos e brincadeiras tínhamos a pesquisa das cirandas e músicas de roda (cacuriá), e justamente esta parte da pesquisa é a que mais necessitava de espaços amplos e abertos, isto é, espaços que não fossem o palco à italiana. (Carlos Quirino Ramalho).
A afinação da coreografia e do canto foi gradativa e deu-se ao longo de todo o semestre de trabalho. Durava em média uma hora e meia por encontro. $\mathrm{O}$ privilégio da música ao vivo com o músico Ramon Vieira permitiu uma pesquisa e experimentação que aos poucos foi sustentando as partituras e os jogos com o Grande Coro, através da pontuação com instrumentos e voz. Nem sempre a construção foi linear ou lógica. Houve momentos de ruptura e construção que nascem na interação entre os atuantes e da atuação com a música. Entre as minhas anotações sobre a encenação observo que o diálogo entre jogo teatral e música foi decisivo para a construção da encenação.

De início, riscávamos o traçado do jogo na rua, próxima à sala de aula na qual trabalhamos. Essas saídas, na busca de espaços adequados para a concretização das partituras de jogo, têm sido de grande valia para a aprendizagem. $O$ jogo pode ser assim experimentado fisicamente no espaço amplo. Experimentar o espaço real do jogo, na rua, em competição com os parceiros, gera energia. A alteração da respiração e tônus muscular, provocados pelas partidas de jogo, é também vital para o teatro, pois essa energia será canalizada para a construção da forma estética.

Lembro que em alguns ensaios as pessoas achavam que ficar jogando não valia a pena, ansiosos que estavam pelo texto e pelas marcações. A mim essa maneira de pensar e agir teatro agradou muito, adoro jogar, e sinto que hoje não tenho dificuldades em pensar e analisar o jogo dentro do trabalho teatral. A energia vital que o jogo consegue inserir na cena é resultado desse processo. (Daiana de Moura Bernardes Coelho). 
Figura 15. Laranja ou Limão.

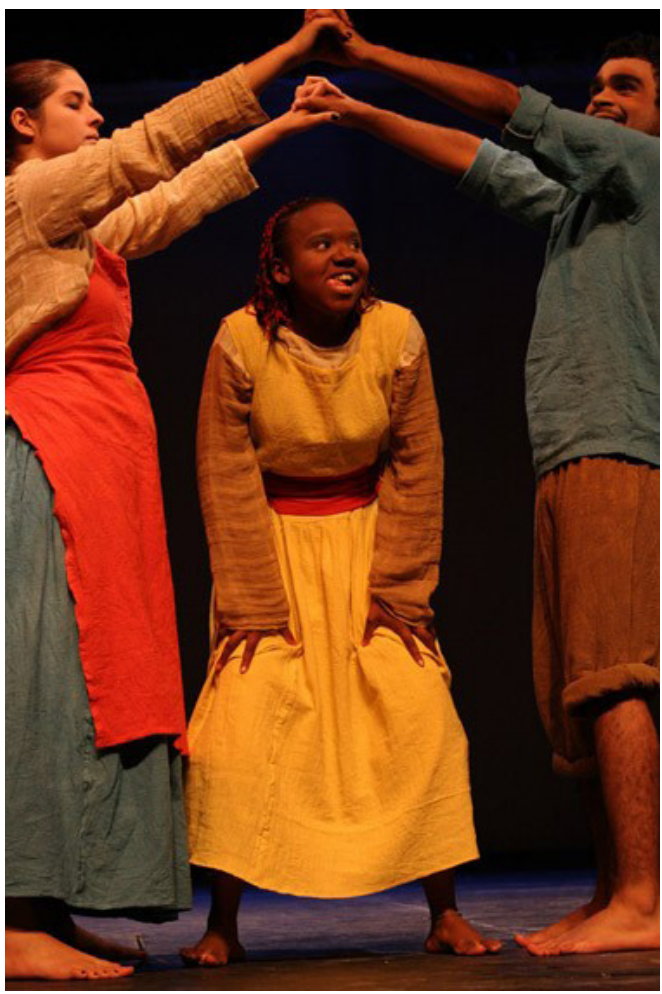

Fonte: Arquivo pessoal da autora.

Aprendidas as regras e ensaiados os coros, retomamos o jogo dos Três Mocinhos de Europa em nosso auditório na UNISO. A coordenação musical de Ramon Vieira levou a uma entonação dos versos do jogo tradicional de forma ritmada, alterando a escuta através do canto do Grande Coro, dando-Ihe qualidade musical.

Figura 16. Música: Ramon Vieira.

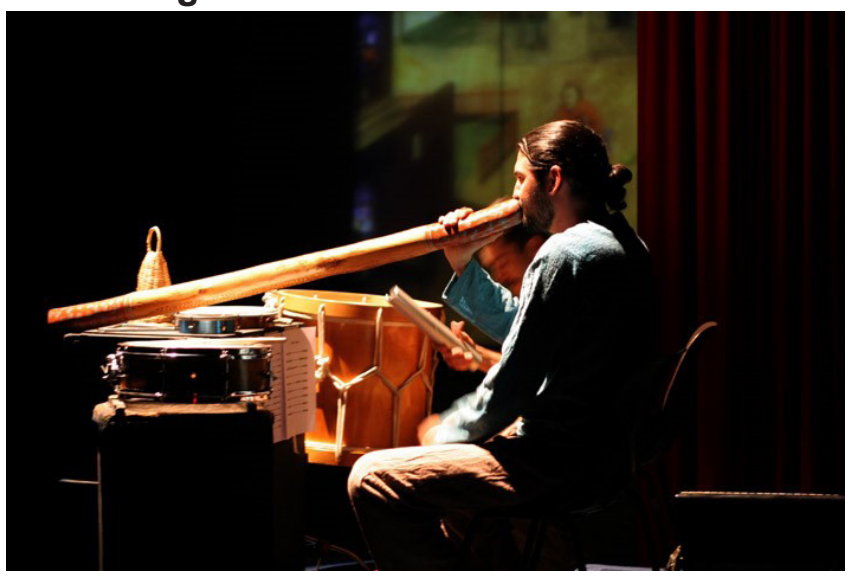

Fonte: Arquivo pessoal da autora.
O acompanhamento instrumental, introduzido pelo músico, provocou transformações no ritmo dos jogos, dando-lhes acentos de rap e samba, entre outros. Esta intervenção musical instigou ainda mais a imaginação dramática dos jogadores. As instruções musicais traziam novos estímulos para a improvisação teatral. O Grande Coro assumia assim o seu espaço, as suas figuras e a sua atividade de cena, fazendo o comentário das partidas de jogo durante toda a encenação.

O jogo teatral Bla-blação (SPOLIN, 2012, p.336) passou a significar a língua dos camponeses (neerlandeses):

Começávamos a compor as figuras da montagem de Nós ainda brincamos como vocês brincavam? Todos estavam sentados no palco (preto com pernas e rotundas de veludo preto), a Ingrid (alta, loira de voz mansa) estava na platéia sentada nas cadeiras (azuis de pernas cinza), propondo à turma que olhasse para a imagem de Peter Brugel, escolhendo uma figura e um nome "neerlandês" para ela. Ficamos um pouco assustados com a proposta, pois não queríamos qualquer nome para a figura escolhida na gravura. D'e forma livre, os atuantes podiam dizer o nome da figura escolhida. Eu não conseguia pensar em nenhum nome com sonoridade interessante. Os nomes das figuras eram cada vez mais caprichados e eu nada... De repente me deu um "clic" e gritei: - Salguod!

- Vocês percebem que o nome criado pelo Douglas tem uma sonoridade interessante? - disse Ingrid.

A Patrícia (cabelos cacheados, avermelhados, de nariz avantajado), muito amiga minha, falou baixinho no meu ouvido:

- Falou qualquer nome né? Garanto que nem lembra mais do que falou...

- É claro que lembro.

- Qual é?

- Salguod!

- Não era esse o nome.

- Claro que era Pá...

- Claro que não seu louca, a Ingrid tem boa memória, ela vai descobrir que você falou qualquer coisa... hahahahaha!

O Leonardo (forte, alto de cabelos cacheados e pretos), estava do nosso lado e ficou só "de ouvido" na nossa conver- 
sa. Nenhum dos dois tinha ainda falado o nome escolhido para suas figuras. Chega um momento que ninguém mais fala nada na roda e Ingrid fica esperando todos completarem. Decidi falar meu segredo para o Léo e para a Pá. - É fácil!

- O que? Respondeu Patrícia.

- É só falar teu nome ao contrário...

- Como assim?

- Ao contrario..

- Tipo... - pensou Patrícia - Aicirtap?

- É, hahahaha.

O Léo ouviu e perguntou:

- Como é que fica o meu?

- Fica... Odranoel_Respondeu Patrícia.

Trabalhamos também com as figuras da época do quadro (o figurino contribui para a caracterização), mas o que dá sentido a essas figuras é a "blablação", o que contribuiu para que as figuras do coro parecessem estar falando uma língua estrangeira.

Figura 17. Bla-blação.

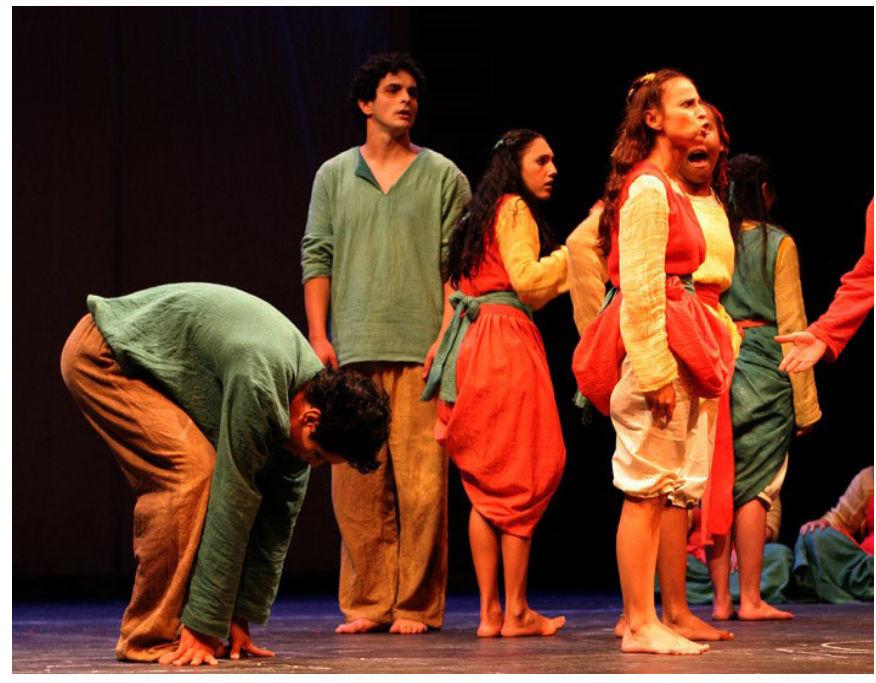

Fonte: Arquivo pessoal da autora.

É o coro que propõe a liga de um jogo para o outro, fazendo com que uma pulsação se integre com a seguinte, o que transformou a encenação em jogo teatral. (Douglas de Camargo Emilio).

Outra cena com o Grande Coro nasceu a partir dos brinquedos, construídos individualmente pelos participantes. Acompanhada pela música (acordeom), esta cena também nasceu de impro- visações a partir da leitura da pintura. Os atuantes realizam atividades de brincar. Brinquedos: dado, bolha de sabão, peteca, bilboquê, bambolê (aro), cama de gato, elástico, boneca de pano, avião de papel, briga de galo, perna de pau, cinco-marias, mané gostoso, cavalo de pau, frisos.

\section{Figura 18. Brinquedos.}

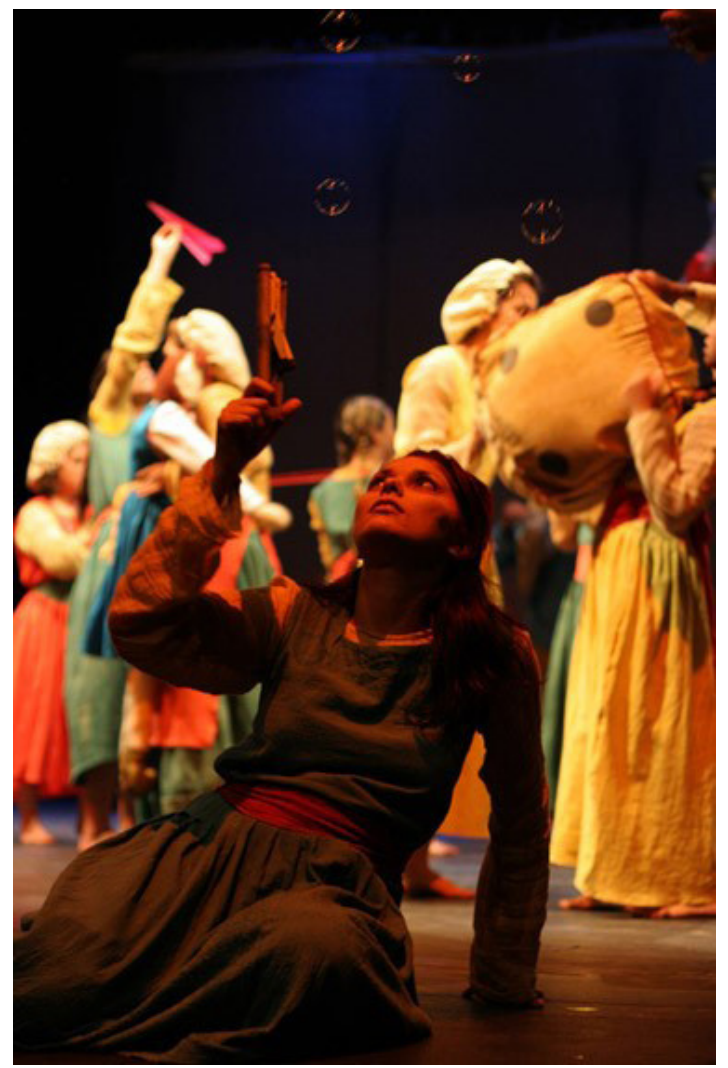

Fonte: Arquivo pessoal da autora.

Figura 19. A explosão da memória.

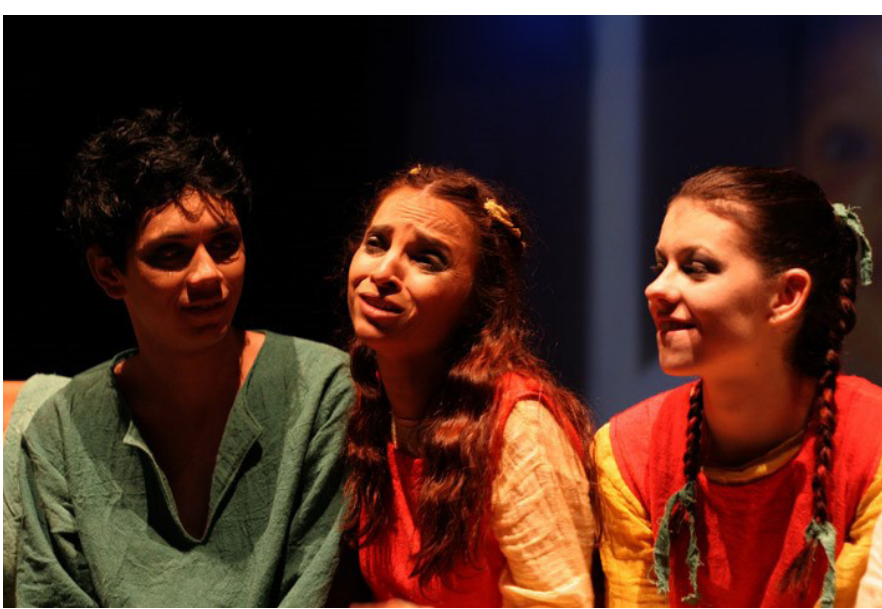

Fonte: Arquivo pessoal da autora. 
A Explosão da Memória, como a denominamos em nosso roteiro (texto cênico), nasceu dos depoimentos sobre a infância dos atuantes, que trouxeram fotos quando crianças.

Este espaço onde os atuantes conversam com a platéia é uma roda de causos onde contamos experiências vividas por nós na infância.

Correr na chuva, catar goiaba, pescar no lago da rua de cima.

Eu tenho duas avós, uma de cabelo branco e outra de cabelo vermelho.

A minha avó de cabelo branco, é bem velhinha e quietinha. Ela dorme o dia intero e não sai de casa pra nada. A minha avó de cabelo vermelho anda de moto, já foi mão de santo, tem um bar e namora um rapaz de vinte anos. Uma vez meu avô estava voltando da venda à noite no escuro. De repente ele escutou um barulho que fazia chic-chic-chi-chic. Ele olhou para traz e nada, então ele andou mais rápido e o barulho aumentava chic-chic-chi-chic. Então ele começou a correr que nem um desesperado e o barulho continuou atrás dele, chic-chic-chi-chic. Quando ele chegou em casa, ele descobriu que era uma caixa de fósforos que estava no bolso dele. Pude perceber que é possível utilizar os jogos para falar com a platéia e até discutir nosso contexto histórico e social, analisar e debater nossa política e história. No processo vivido com a Ingrid, pude perceber o quanto minha história de vida está presente em meu corpo até hoje e como é possível resgatar essa história e comunicá-la ao outro. (Danilo Silveira).

\section{Iluminação}

Algo bem interessante foi o projeto interdisciplinar. Tivemos a orientação do Prof. Gil Camargo na iluminação, a artista-convidada Elena Toscano na coordenação do figurino, o musico-convidado Ramon Aires e o coordenador pedagógico do Curso de Licenciatura José Simões de Almeida na produção da montagem. (André da Silva Barros).
Figura 20. Iluminação.

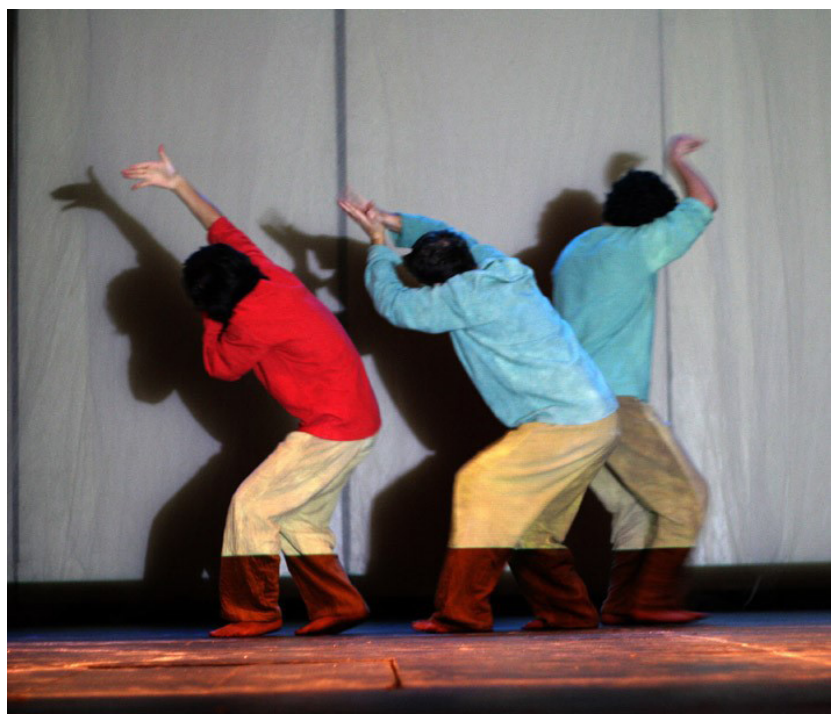

Fonte: Arquivo pessoal da autora.

No dia da estreia, às $08 \mathrm{~h} 00 \mathrm{hs}$, estava no Teatro Municipal apenas a equipe técnica, o pessoal da iluminação, imagem e figurino. Neste dia fiz questão de ir. Durante o ajuste da iluminação, tivemos uma ótima aula prática. $O$ fato de poder ver os holofotes e a cabine de luz ajudou muito na compreensão da teoria. Durante toda a manhã observamos atentos às instruções do Prof. Gil Camargo aos técnicos do teatro. $O$ ensaio de luz e sua afinação seriam feitas a tarde durante o ensaio geral. A iluminação surpreendeu, as roupas criaram vida. Já no Teatro Municipal de Votorantim, tivemos outra experiência, tanto na montagem da lluminação, que foi inteiramente feita por nós, os alunos. Instalamos um ciclorama que permitiu uma maior definição da imagem. Eram 9:00 horas, quando cheguei no teatro. Descobrimos que não teríamos ajuda de técnicos. Teríamos que subir nas escadas e regular as luzes. Fizemos a afinação em trio: Eu, o Leonardo e o Vinícius (Zulu). Mas quem teve que subir fui eu... Foi uma ótima experiência! Sob o comando do Professor Gil, íamos iluminando as áreas, trocando as gelatinas, etc. Seriam duas apresentações. Já na primeira tivemos uma pequena surpresa: um dos PCs teve a lente estourada, caindo aos cacos em meio à apresentação. Por pouco não cai em cima de alguém ... causando um ferimento grave. Como eu sabia que aquele vidro deveria estar muito quente, corri até o camarim para pegar um pano e uma vasilha para por os cacos dentro. Po- 
rém o elenco resolveu improvisar. Alguns pegaram os cacos com a mão, sofrendo pequenas queimaduras. $O$ incrível é que $O$ espetáculo não parou. Durante o decorrer das cenas sempre tinha alguém pegando cacos no pé (isso deve doer!). Uma das meninas, a Carina, teve que sair de cena durante um bom tempo, pois um caco foi fundo no pé dela. Só conseguiu tirar com ajuda das colegas, sem graves conseqüências. Fora esse problema que segundo o responsável pelo teatro nunca tinha ocorrido, não tivemos outras surpresas ruins. Na verdade, penso que nesse teatro foram feitas as melhores apresentações da temporada. Uma coisa é apresentar aqui em Sorocaba ou Votorantim, outra é apresentar para um público formado por pessoas que não conhecemos, e pior, que trabalham com arte/ educação e teatro. (Carlos Quirino Ramalho).

\section{Figura 21. Na USP.}

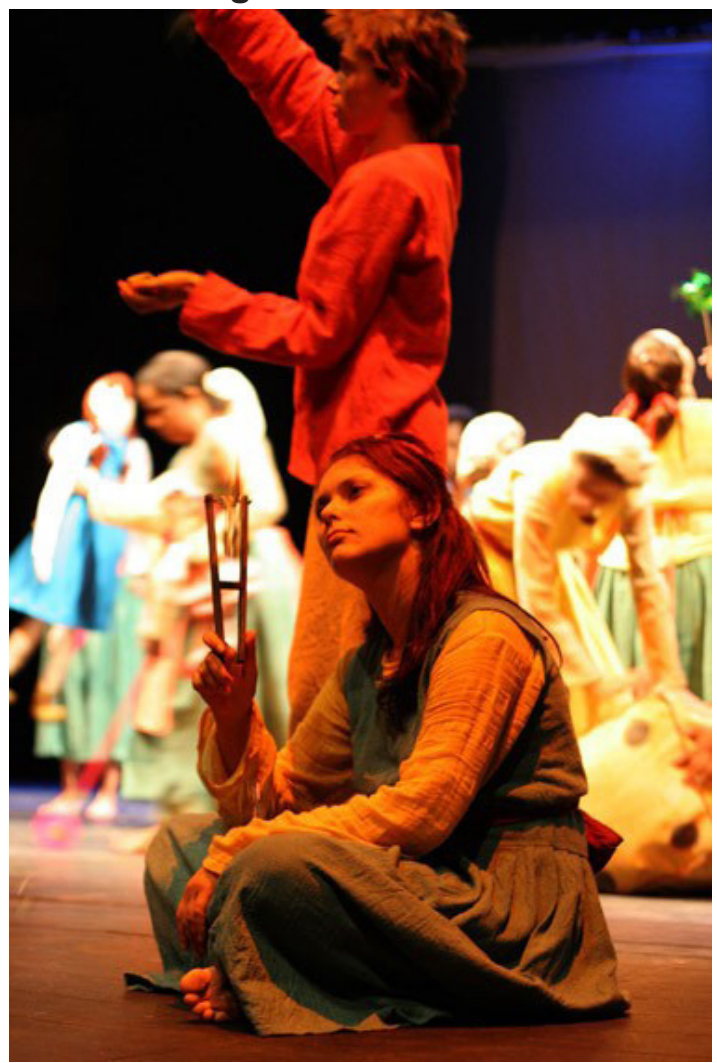

Fonte: Arquivo pessoal da autora.

Estávamos todos muito apreensivos com a apresentação na USP - Teatro Alfredo Mesquita, tanto que eu fui escalado para ir dias antes para ajudar na iluminação. Foi feita uma "vaquinha" para pagar a passagem. Fiquei maravilhado com o acolhimento das pessoas que trabalham lá e princi- palmente com os recursos técnicos de iluminação do local onde iríamos apresentar. No dia da apresentação não tivemos a experiência do Prof. Gil nos controles de luz, mas a determinação de um aluno do segundo ano, Emerson. Isso me fez pensar na importância de criar, durante a montagem do espetáculo, condições para que alunos se envolvam em outras áreas, não somente atuação. De minha parte, a felicidade de ter participado de um projeto bonito, que já reverbera junto a meus alunos adolescentes na sala de aula e aprender sobre jogo popular e jogo teatral de forma tão gostosa, já valeu a pena. Penso que todas as descobertas e aventuras só foram possíveis graças à mediação da Ingrid, uma pessoa iluminada. Obrigado, professora! (Carlos Quirino Ramalho).

O light design da luz foi desenvolvido pelo Prof. Dr. Roberto Gil Camargo, que atuou como um jogador com a luz, contribuindo assim para estética do jogo teatral no espetáculo. A luz respirou junto com os atores em cena. Cada movimentação, fala, imagem, música contou com essa outra parceria de jogo, que ajudava a evidenciar a estética da encenação. $\mathrm{Na}$ cena dos brinquedos, o Prof. Gil criou uma luz atmosférica que junto ao acordeom do músico Ramon Vieira deram o peso e a intenção para a cena. A integração da luz com os jogos e as outras artes cênicas aconteceu em sintonia, já que nenhum desses elementos era mais evidente que o outro. (Leonardo Rariz Machado).

\section{Figurinos}

Os figurinos, projetados a partir da imagem de Peter Brugel estão se configurando como uma das chaves do processo de criação. Roupas, cores, expressões fisionômicas das crianças/adultos foram objeto de observação a partir da forma estética da pintura. Sobreposições de cores e tecidos foram cogitadas, na busca do caminho da pesquisa. 
Figura 22. As figuras de Pieter Bruegel.

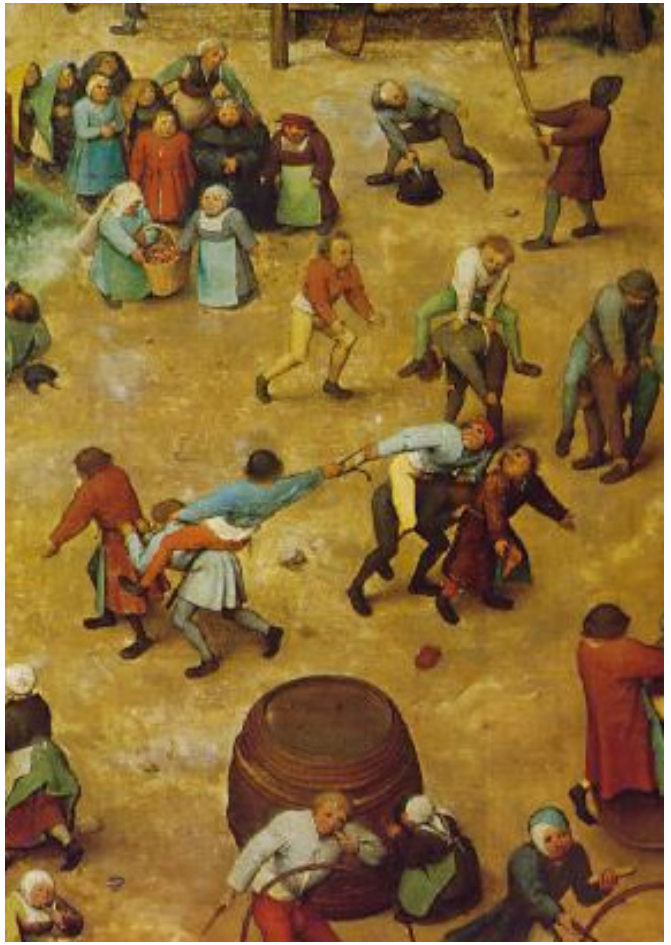

Fonte: Children's Plays, Wikimedia Commons, Public Domain.

Os rostos das crianças/adultos camponeses brincando/jogando em praça pública, na rua, são interrogados sobre a atividade que realizam. Com as fisionomias chapadas, sem expressão de alegria ou pesar, essas figuras estão envolvidas em atividades de jogo. As pulsações do texto espetacular foram criadas a partir dos jogos de rua que pudemos identificar. Característica destes jogos são as regras estabelecidas a partir de acordo entre os parceiros.

Os jogadores foram maquiados dando destaque às fisionomias da pintura de Brugel. Figurino e maquiagem promovem o estranhamento das figuras, remetendo ao tempo histórico e tornando os gestos e atitudes de jogo estendidas.

\section{A confecção dos figurinos}

A elaboração dos figurinos partiu de uma pesquisa das vestimentas das figuras de Peter Brugel, a partir de seu estilo, época e cores. A professora responsável pelas aulas de figurino, a artista Elena Toscano, direcionou o tecido das roupas, bem como dos acessórios que completavam a indumentaria.
Fizemos esboços dos figurinos a serem confeccionados. Várias propostas foram estudadas e decidiu-se por dois modelos femininos e um masculino.

Para a confecção desses figurinos, foram necessárias horas de investigação para resolver que tipo de tecido se aproximava mais da textura com aspecto envelhecido. Um dado importante era a mobilidade da roupa, já que estávamos trabalhando com jogos, que exigiam grande movimentação por parte do elenco.

A aluna Cíntia trouxe amostras de tecidos para aprovação. Conhecido por "pano de saco" foi aprovado um tecido que tinha um tom bege, meio rústico e não industrializado. O outro chamado de "fralda", por ser um pano fino e de fácil secagem, foi escolhido por dar a impressão de desgastado.

Todos os tecidos foram analisados quanto ao valor e entregues a faculdade que arcou com todos os gastos referentes à primeira compra. As demais compras foram pagas pelos próprios alunos, durante o processo.

Figura 23. Figurinos.
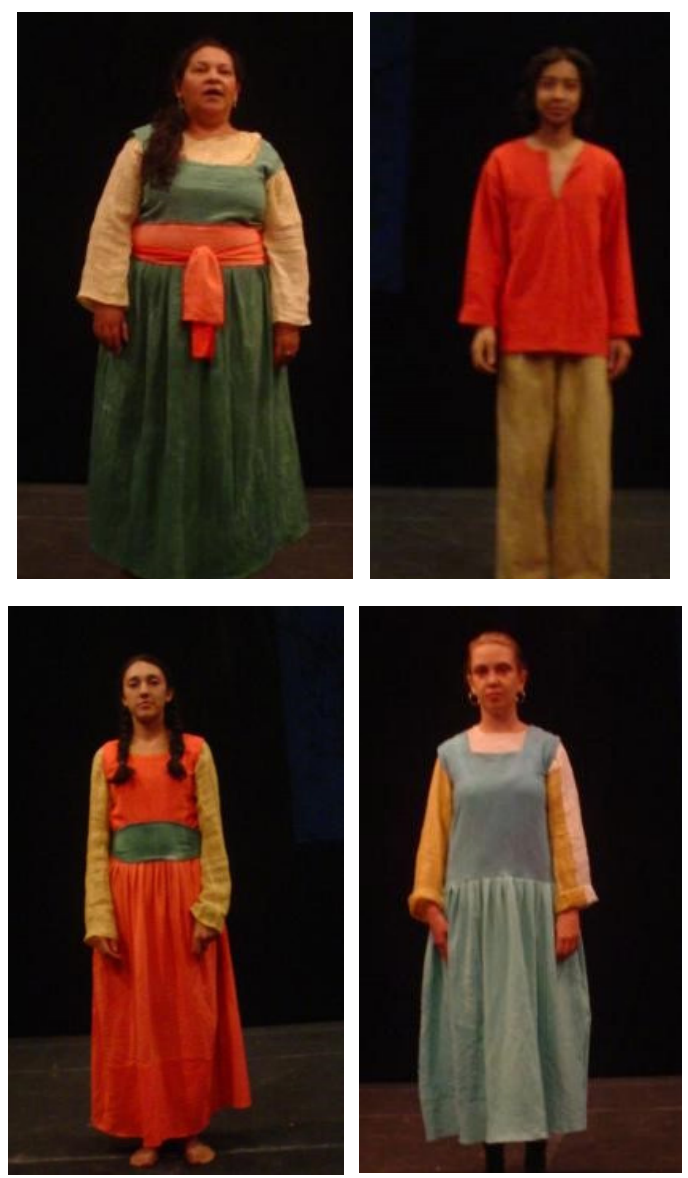

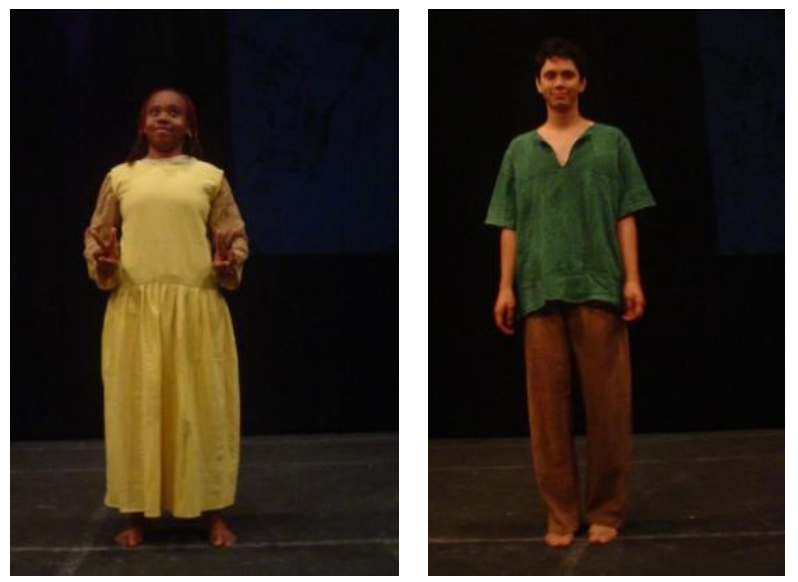

Fonte: Arquivo pessoal da autora.

\section{Feminino 1 \\ - Blusa manga comprida (pano de fralda) \\ - Vestido (pano de saco) \\ - Calçola (pano de saco) \\ $\bullet$}

\section{Feminino 2}

- Blusa manga comprida (pano de fralda)

- Saia (pano de saco)

- Avental (pano de saco)

-

\section{Masculino}

- Calça (pano de saco)

- Camisa manga comprida (pano de fralda)

Foram introduzidas calçolas para os figurinos femininos, devido à necessidade de movimentação no palco, principalmente nos jogos de Voo.

\section{Escolha das cores}

A solicitação da Profa. Elena quanto às cores foi a seguinte:

As cores quentes seriam usadas nas meninas menores por aumentar a silhueta e as frias para as maiores, com o intuito de diminuir o tamanho. As cores utilizadas foram: vermelho, amarelo, azul, verde e ocre (mistura de amarelo e marrom), combinadas de acordo com as peças do figurino:

\begin{tabular}{|l|l|}
\hline Saia & Avental \\
\hline Azul & Vermelho \\
\hline Verde & Vermelho \\
\hline vermelho & azul \\
\hline \multicolumn{2}{|l|}{} \\
\hline \multicolumn{2}{|l|}{ Faixa (cintura) } \\
\hline Vestido & faixa \\
\hline Amarelo & Vermelha \\
\hline Vermelho & verde \\
\hline
\end{tabular}

\section{Sapato}

No início havia a idéia de ser usado um sapato com solado. Mas optou-se por trabalhar descalço para melhor movimentação no palco.

\section{Tingimento}

Os tecidos foram tingidos antes de serem confeccionados. Um grupo de três pessoas ficou responsável pelo tingimento para que não houvesse nenhum tipo de contratempo, como por ex: cores diferentes, manchas nos tecidos etc.

O primeiro local que foi usado para a atividade, foi a Escola Salvador Ortega Fernandes (Bairro Itavuvu - Sorocaba). O segundo e ultimo tingimento foi feito na casa de uma das integrantes do grupo.

Os problemas enfrentados pela equipe envolviam desde transporte dos materiais, até o corte feito por engano dos tecidos na hora de tingir. Isso dificultou o trabalho da costureira quando os tecidos encoIhiam. A cor azul, no primeiro tingimento ficou muito clara, precisando refazer o processo. Foi preciso usar marrom e amarelo para chegar ao tom correto do ocre.

\section{Fervura dos tecidos}

Os tecidos ao passarem pelo processo da fervura tinham diferentes reações. A fralda, por exemplo, não precisava ficar na fervura para obter a cor, já o pano de saco necessitava de uns 30 minutos no fogo.

No começo, os panos secos não contribuíam para dar uma cor uniforme. Depois de umedecidos, a cor fixava mais. Outra questão que incomodava era que depois de tingidos, os tecidos ficavam mais pesados, dificultando o transporte até o varal. 
Essa atividade de tingimento nos fez pensar que é como se fosse um jogo teatral - com problemas a serem resolvidos. A equipe trabalhou para que 0 acerto no jogo do tingir implicasse em muitas adequações, de forma a não perder o foco das cenas.

$\mathrm{Na}$ foto abaixo Silvia e Camila mexendo os tecidos para a fervura, na casa da Camila.

Figura 24. Fervura de tecidos.

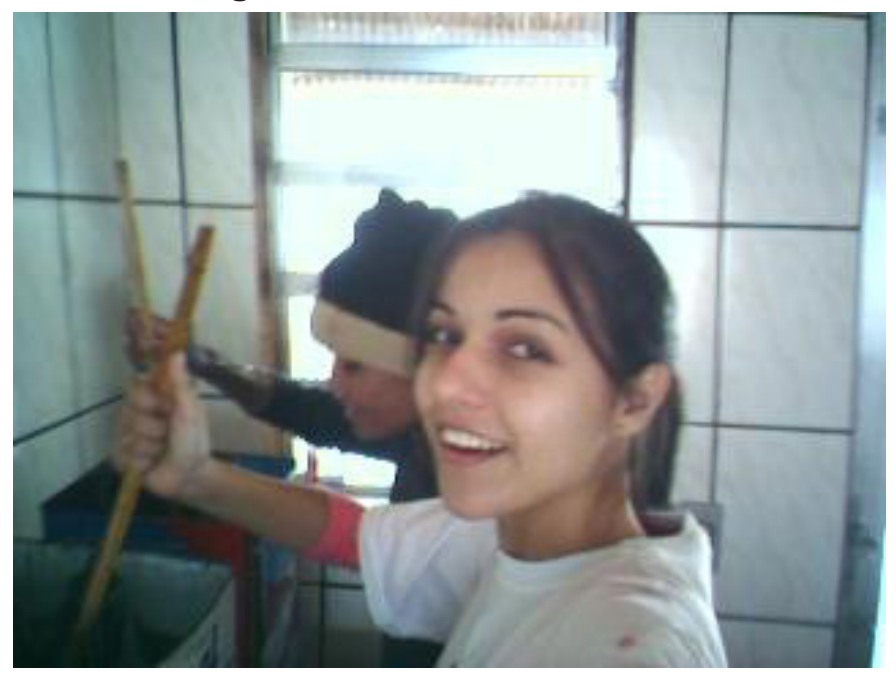

Fonte: Arquivo pessoal da autora.

Figura 25. Mãe da aluna/atriz Camila fervendo o tecido.

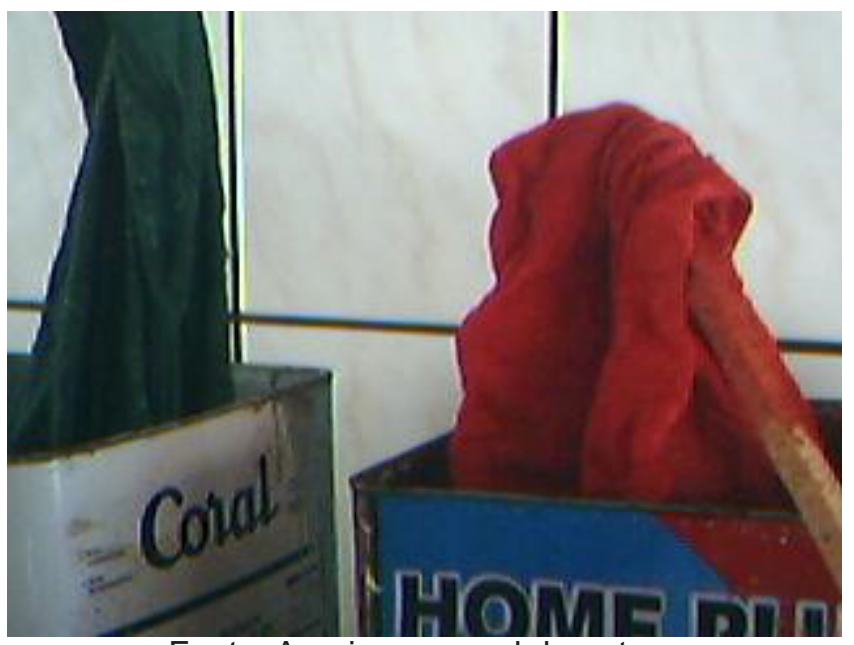

Fonte: Arquivo pessoal da autora.
Figura 26. Os tecidos secando no varal improvisado com cadeiras.

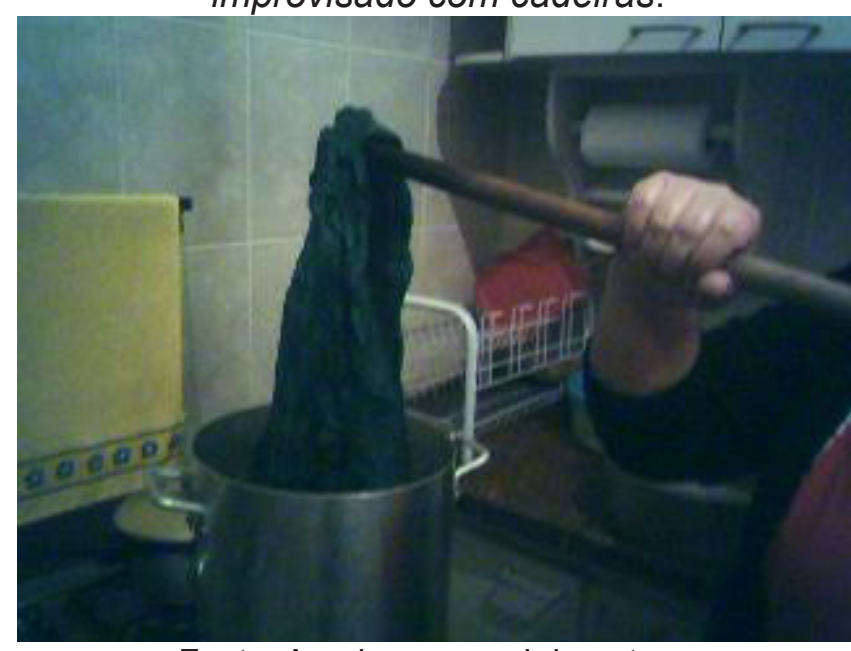

Fonte: Arquivo pessoal da autora.

Figura 27. Os tecidos já tingidos.

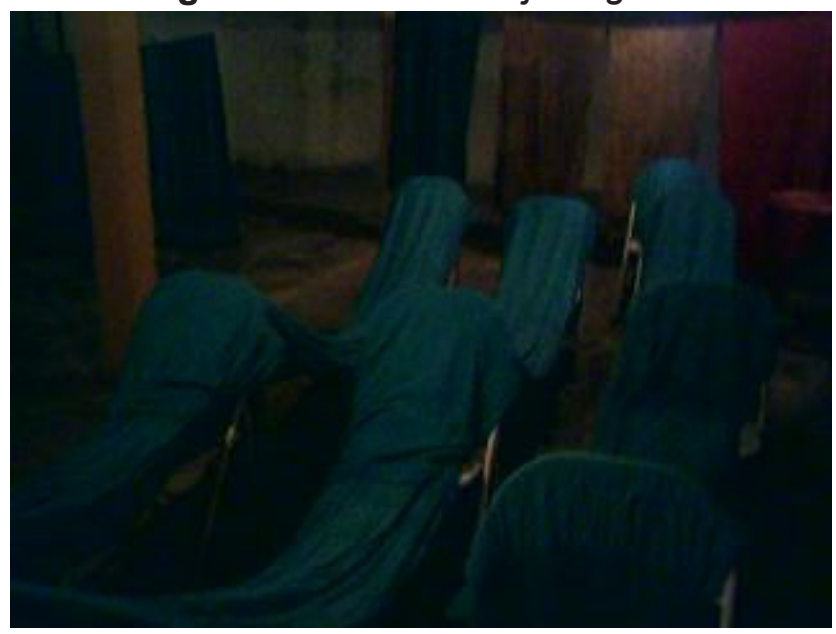

Fonte: Arquivo pessoal da autora.

Repare que na figura 25 a luz do sol está batendo na janela e na 26 já é noite.

Levou o dia todo, tingimos mais ou menos cem metros de tecido. (Camila Mantovani Balieiro; Cynthia Jordão Costa; Silvia Pereira do Nascimento).

Os trajes, baseados nas figuras de $\mathrm{Pe}$ ter Brugel, transportaram-nos a um período histórico. A indumentária era um dos códigos que nos faziam duplicar o olhar - de um tempo histórico dando significado ao nosso tempo. 


\section{As apresentações do espetáculo}

Figura 28. Platéia no Teatro Antônio Vilela.

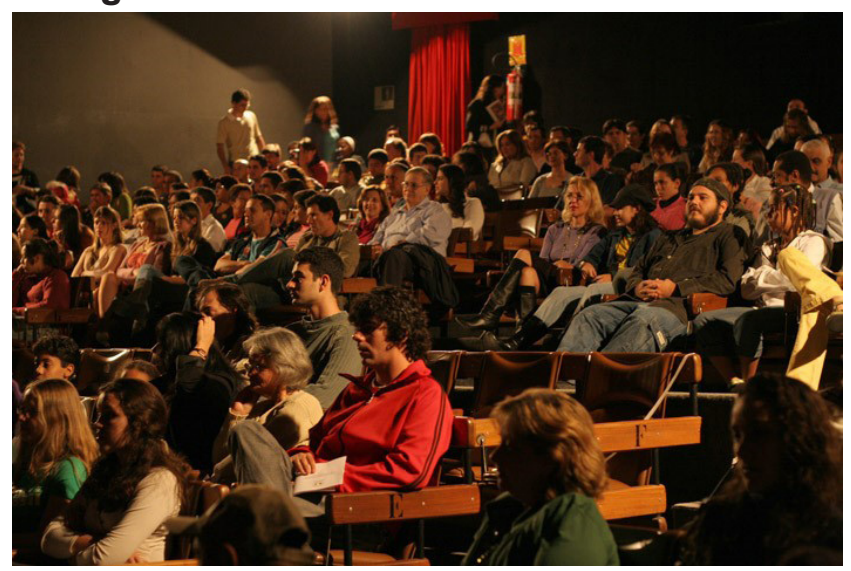

Fonte: Arquivo pessoal da autora.

Pra mim, nossa estreia foi a melhor apresentação feita até hoje, um momento único e muito especial. Uma segunda coisa mais importante do que essa, foi a presença de minha avó Geny. Foi o primeiro trabalho que ela assistiu e o último, pois veio a falecer pouco tempo depois. Até a sua vizinha me disse da felicidade e orgulho que minha avó teve ao assistir o espetáculo e me ver no palco. Antes deste dia, ela não aceitava muito a vida com o teatro. Foi com a nossa encenação que ela pode mudar seu olhare, portanto, admirar minha profissão. Interessante também salientar sua presença na minha infância vivida toda ao seu lado. As brincadeiras, cantigas e memórias do espetáculo eu aprendi na rua de sua casa. E pude relembrar reproduzindo-as em partituras. A minha rua nunca teve graça, pois só morava gente ou muito velha ou muito criança. Eu passava a maior parte do tempo na casa da avó Geny, numa rua plana e calma, numa casa cuja porta dá pra rua, diferente da casa dos meus pais que é um sobrado e que acaba por nos isolar das pessoas. Foi minha avó linda que me ensinou a rezar, amarrar os cadarços do tênis, me dava um leitinho quente antes de dormir, me cobria na cama e me dava um beijinho de "boa noite durma com Deus" na testa. Um tempo feliz que com a oportunidade do espetáculo me fizeram ter orgulho de minha infância simples e ingênua, cheia dos carinhos da avó. Depois da apresentação conversei com ela e juntas, lembramos do que eu mais gostava fazer, brincar, comer, aprontar, enfim, pude relembrar momentos e trazer assim mais sensações, sentimento de grande importância para o espetáculo.

Conversando com mais pessoas após a apresentação, era notável o entusiasmo de quem nos assistiu. As pessoas vinham me contar coisas que faziam na sua infância; contavam suas histórias; perguntavam porque não colocamos aquela ou aquela outra brincadeira que faltou; falavam da vontade de sair dali brincando e pulando. Muitas tiveram vontade de subir ao palco e jogar junto. Comentários como estes foram frequentes. (Aline Martins Nieri).

Figura 29. Aline.

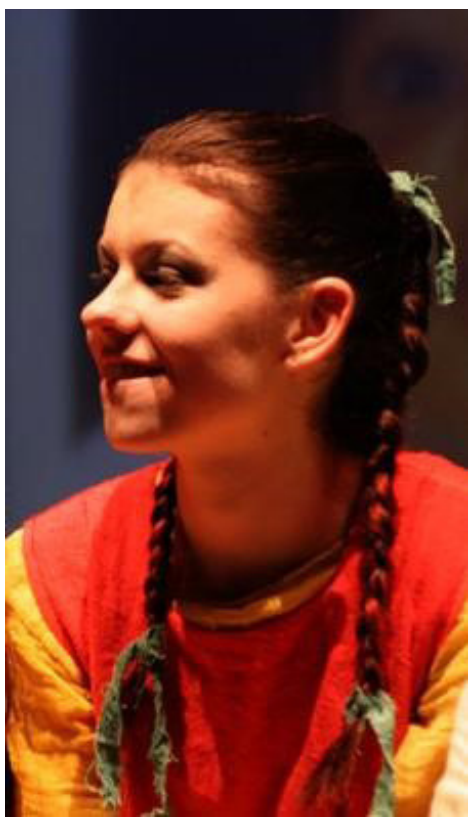

Fonte: Arquivo pessoal da autora.

Depois de muito trabalho, de muito jogar agora era o momento de mostrar o trabalho. A primeira apresentação foi muito importante para mim, pois seria este o momento em que meus pais veriam o meu trabalho, me veriam. O que tornou este momento especial foi a minha história de vida. O relacionamento com meus pais fez acender uma estrela dentro dos meus olhos, que brilha com muita intensidade a cada palavra que estou escrevendo. Esta foi a primeira vez que meus pais saíram daquela cidadezinha no interior do mundo e entrariam em um teatro, para me ver. E eles gostaram! Gostaram de ver todos em cena, de me ver, ficaram muito emocionados em ver que o menininho deles cresceu. (Marcio Ribeiro Murat). 
Figura 30. Marcio.

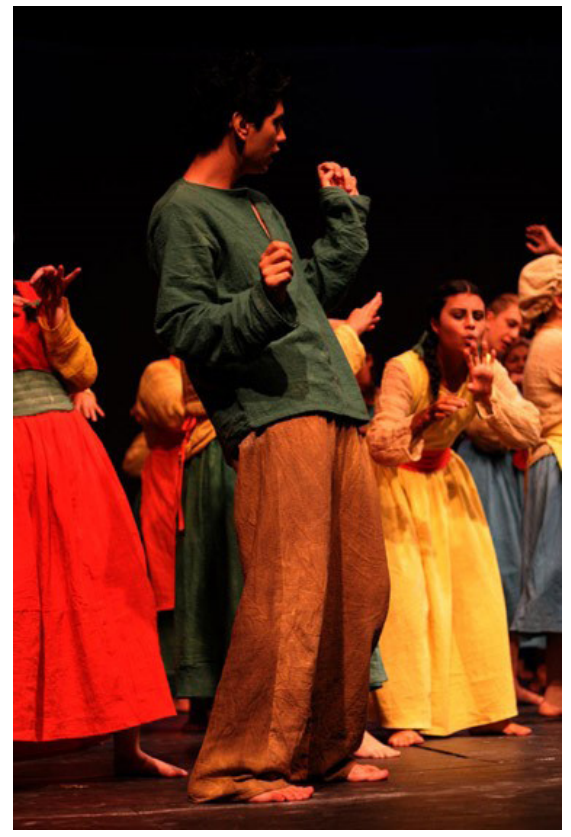

Fonte: Arquivo pessoal da autora.

Pude perceber ao conversar com espectadores, que eles se sentiam fascinados pelos jogos e o espetáculo fez com que o público remetesse as suas próprias lembranças da infância. Penso ser significativa essa identificação que o trabalho proporcionou ao estimular a memória do público. (Matilde Aparecida dos Santos).

\section{Figura 31. Matilde.}

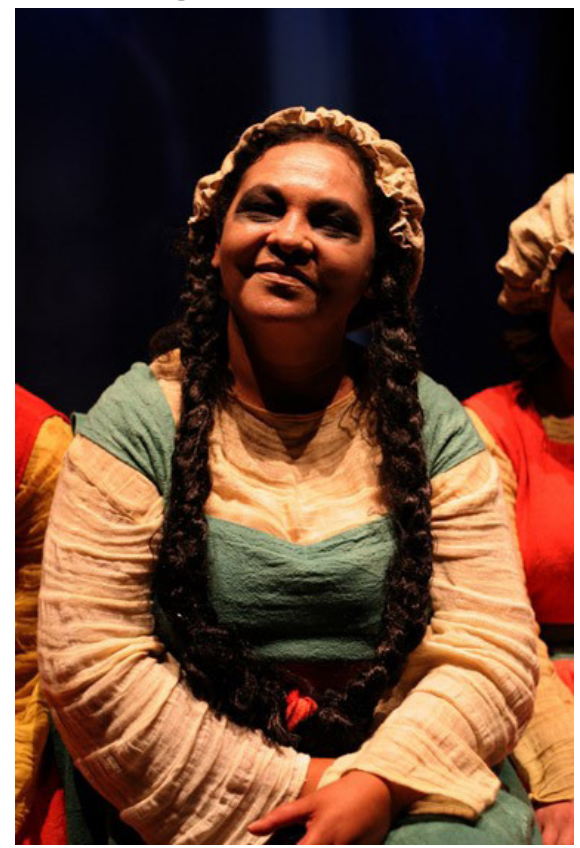

Fonte: Arquivo pessoal da autora.
No dia da estréia, foi a maior correria. Ensaiamos no período da tarde, algumas pessoas foram montar o cenário junto com a Profa. Elena de manhã. Vários problemas surgiram e arrumamos a primeira cena uma hora antes de começar o espetáculo. As pessoas correndo pelos camarins do teatro atrás dos figurinos, da maquiagem, do cabelo. Todos nervosos, tremendo. Mas quando o terceiro sinal apitou, a cortina se abriu e vimos a platéia lotada, conseguimos nos concentrar e fazer um belo espetáculo. (Camila Mantovani Balieiro).

\section{Considerações}

Nas imagens alegóricas de Brugel, as figuras parecem estar congeladas, como que suspensas. Essa imobilização está intimamente ligada ao seu caráter narrativo e alegórico. Elas estão desdramatizadas. Cada detalhe tem o mesmo peso. Não há lugar para a culminância e a centralização típicas da representação dramática, como a separação de assunto principal e secundário, centro e periferia. Com frequência, o alegorista desloca a narrativa principal, de modo acentuado, para a margem.

Essa estética da crônica fascinava especialmente Brecht, que estabeleceu uma ligação entre a pintura de Brugel e a sua concepção do gênero épico. Nas observações que escreve sobre O Efeito de Estranhamento nas Pinturas Narrativas de Peter Brugel, o Velho, tal efeito modelar sobre a sua própria obra se evidencia:

Se investigarmos os fundamentos dos contrastes pictóricos de Brugel, nos apercebemos que apresentam contradições (...) mesmo quando equilibra seus opostos, Brugel não os equipara uns aos outros. Não existe nessas imagens uma separação entre o trágico e o cômico. $O$ trágico contém o cômico e o cômico, o trágico. (BRECHT, 1967, p. 280).

O ponto de fuga da construção histórica se realiza no presente. De acordo com Benjamin “(...) não se trata de apresentar as obras literárias no contexto de seu tempo, mas de apresentar, no tempo em que elas nasceram, o tempo que as revela e conhece: o nosso (...)" (BENJAMIN, 1986, n.p). Ou seja, deciframos a nossa época através de obras do passado. 
Entendemos que pela leitura do passado buscamos elementos para apontar para as contradições do presente. A obra de Bruegel traz as práticas de jogo dos homens do século XVI. Por outro lado, no presente a obra possibilita debater as transformações que estão ocorrendo hoje e expressam nosso modo de vida em sociedade. O jogo contribui para educar o corpo, as atitudes e os gestos do homem em determinados momentos históricos.

Frente ao teatro tradicional, cujo intérprete se baseia na palavra, o teatro como alegoria constitui-se como uma forma cênica própria, sob diferentes pontos de vista, favorecendo a alegorização da cena que destaca o texto e/ou imagem, abrindo espaço de jogo para o imaginário do leitor, atuante ou espectador.

A pintura de Brugel (1560) não é uma representação realista da praça renascentista. $O$ caráter ancestral da obra lhe confere o caráter de alegoria. A proposta pedagógica implica em um processo anti-didático, aberto para a polifonia de significados, permitindo que os atuantes não precisem passar pela autoridade do encenador. A obra de arte é mediada através da prática do jogo teatral. A encenação como prática pedagógica é um teatro no qual a alegoria gera espaço dialógico através do jogo.

Hoje encontros virtuais estão sendo priorizados no relacionamento entre alunos e professores. O jogo teatral com a alegoria oferece uma abordagem metodológica na qual a autonomia e o afeto podem ser preservados nesse processo de ensino/aprendizagem.

O jogo teatral com a alegoria promove a experiencia estética, a ser exercitada pelo atuante na teoria e na prática. $\mathrm{O}$ arte-educador é convidado a participar de uma aventura na qual a alegoria é tratada como processo de aprendizagem e descoberta através de imagens e textos poéticos que podem nos ajudar a conquistar novas percepções.

Imagens e/ou textos alegóricos mobilizam símbolos e percepções sensoriais. Este jogo de descobertas potencializa o olhar e a escuta para a construção de significados simbólicos.
Referências

ANDRADE, M. O turista aprendiz. Brasilia: IPHA, 2015.

BENJAMIN, W. Documentos de cultura, documentos de barbárie. Escritos Escolhidos. Seleção e apresentação: Willy Bolle. São Paulo: CultrixIEDUSP, 1986.

BRECHT, B. Verfremdungseffekt in den erzählenden Bildern des älteren Bruegel (O efeito de estranhamento nas pinturas narrativas de Peter Brüghel, o Velho). Tradução de Ingrid Koudela. In: BRECHT, GW 18. Frankfurt: Suhrkamp, 1967.

BRUEGHEL, P. Children's Plays. Óleo sobre tela 118 x $161 \mathrm{~cm}$, Kunsthistorisches Museum, Viena. 1560.

BRUEGHEL, P. The Elder, Public Domain, via Wikimedia Commons. Acesso: 18 fev. 2021.

PIAGET, J. A formação do símbolo na criança. Rio: Zahar, 1975.

PIAGET, J. O julgamento moral na criança. São Paulo: Mestre Jou, 1977.

SIMAS, L.A. O corpo encantado das ruas. Rio de Janeiro: Ed. Civilização Brasileira, 2020.

SPOLIN, V. Jogos Teatrais: O fichário de Viola Spolin. Apresentação e tradução: Ingrid Dormien Koudela SP: Ed. Perspectiva, 2001.

Jogos teatrais na sala de aula. Apresentação: Ingrid Koudela SP: Ed. Perspectiva, 2006.

. Jogos teatrais no livro do diretor. $2^{\mathrm{a}}$ edição. Apresentação: Ingrid Dormien Koudela Tradução: Eduardo Amos e Ingrid D. Koudela São Paulo: Ed. Perspectiva, 2010.

Improvisação para o Teatro. $5^{\mathrm{a}}$ edição. Apresentação: Ingrid Dormien Koudela Tradução: Eduardo Amos e Ingrid D. Koudela. São Paulo: Ed. Perspectiva, 2012. 
Recebido: 24/02/2021

Aceito: $11 / 03 / 2021$

Aprovado para publicação: 29/05/2021

Este é um artigo de acesso aberto distribuído sob os termos de uma Licença Creative Commons Atribuição 4.0 Internacional. Disponível em: <http://creativecommons.org/licenses/by/4.0>.

This is an open-access article distributed under the terms of the Creative Commons Attribution License 4.0 International. Available at: <http://creativecommons.org/licenses/by/4.0>.

Ce texte en libre accès est placé sous licence Creative Commons Attribution 4.0 International. Disponible sur: <http://creativecommons.org/licenses/by/4.0>. 